
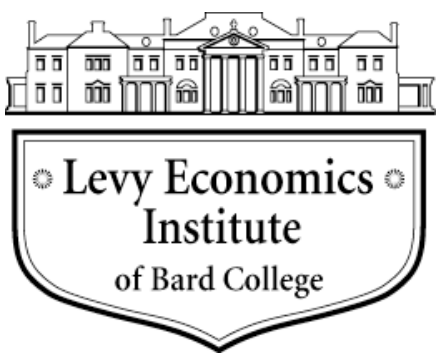

Working Paper No. 790

\title{
Changes in Global Trade Patterns and Women's Employment in Manufacturing: An Analysis over the Period of Asianization and Deindustrialization
}

\author{
by
}

\author{
Burça Kızılırmak \\ Ankara University \\ Emel Memiş \\ Levy Economics Institute of Bard College \\ Şirin Saraçoğlu \\ Middle East Technical University \\ Ebru Voyvoda \\ Middle East Technical University
}

March 2014

\footnotetext{
*The authors kindly acknowledge financial support from TUBITAK (The Scientific and Technological Research Council of Turkey), Project No. SOBAG 109K510. We are grateful to the session participants at the 22nd IAFFE Annual Conference, ICE-TEA 3rd International Conference, and 16th IEA World Congress, and to the participants of the seminar at Ankara University. All remaining errors and views expressed herein remain the responsibility of the authors.
}

The Levy Economics Institute Working Paper Collection presents research in progress by Levy Institute scholars and conference participants. The purpose of the series is to disseminate ideas to and elicit comments from academics and professionals.

Levy Economics Institute of Bard College, founded in 1986, is a nonprofit, nonpartisan, independently funded research organization devoted to public service. Through scholarship and economic research it generates viable, effective public policy responses to important economic problems that profoundly affect the quality of life in the United States and abroad.

Levy Economics Institute

P.O. Box 5000, Annandale-on-Hudson, NY 12504-5000

http://www.levyinstitute.org

Copyright (C) Levy Economics Institute 2014 All rights reserved 


\begin{abstract}
The purpose of this study is to explore the employment effects of changes in manufacturing output resulting from shifting trade patterns over the period 1995-2006. For 30 countries (21 OECD and 9 non-OECD countries) we estimate the changes in embodied labor content due to trade using factor-content analysis, breaking up the sources of these changes between trade with the North, the South and China. We also decompose changes in employment into its component changes within and across sectors. Our results present a net negative impact of trade on total employment in 30 countries over the period of analysis (despite employment gains in 17 countries). Except for the Philippines and the Republic of Korea, trade with China has a negative impact on total employment in all countries, with a stronger negative effect on women's employment. Employment losses in the South due to a surge in imports from China are coupled with declining exports to the North, as many countries in the North shift their imports to emerging economies in Asia. Decomposition results indicate that the decline in the share of women's employment is mainly due to shifts between sectors rather than changes within sectors. Changes in women's employment are still highly dependent on movements in "traditional" manufacturing sectors, including food, textiles, and wearing apparel.
\end{abstract}

KEYWORDS: North-South trade; Decomposition Analysis; Factor Content Analysis; Gender Bias

JEL CLASSIFICATIONS: F16, J16, J21 


\section{INTRODUCTION}

Employment outcomes of trade in manufacturing goods between the developed (North) and developing countries (South) have long been debated in development literature. Since the 1970s, an increasing number of developing countries joined the global manufacturing trade and have become major exporters to the North. In early work at the beginning of 1980s, the net employment effect of surging North-South trade was found to be negligible (among others see Krueger, et al. 1981). These debates were revived by Wood (1991), when he showed far greater impact of the North-South trade on employment: along with employment gains recorded in the South, major employment losses occurred in the North over the period 1968-81. Exploring changes in trade patterns over the period 1995-2006 in 30 countries and extending available evidence up to the mid-2000s, the current paper aims to contribute to these discussions.

Wood has also made a notable argument specific to women's employment, arguing that increased North-South trade has asymmetric outcomes for women's employment share in the North and South (also known as the Wood-asymmetry). Accordingly, while in the South women's employment was increasing in absolute and relative terms bringing a rise in female share, - unlike the basic trend in total employment - there was no decline in female share in the North. Kucera and Milberg $(2000,2003)$ revisited Wood's arguments and provided evidence up to the mid-1990s. Supporting Wood's findings, they found large losses in total employment in OECD countries as a result of North-South trade; however their results overturn Wood asymmetry indicating significant gender bias in employment effects of trade in the North.

Earlier studies have mainly focused on the OECD countries and their trade partners. Since the mid-1990s there have been major shifts in global manufacturing production and trade structure. New actors in world trade have emerged along with the implementation of multilateral and regional trade agreements. The rise of "emerging economies" as important manufacturing producers and trading partners has brought substantive shifts and changes in the geography of production and international trade. "Asianization" in production, a term used to define a highly import-dependent structure in manufacturing production and trade arose to describe such trends. It has been observed not only in the North but in the South, as well. This is particularly so for middle income and mid-high income countries in the South. It would not be wrong to say that pooling the countries outside or within the OECD into a single group has become impossible. Given all these shifts, here we seek to answer whether the employment impacts of North-South 
trade observed in the 1990s prevail in the 2000s. Do these results vary among different country groups and/or by industries and do they vary among women and men? We believe that answers to these questions cannot be obtained by analyzing the country groups only, but more detailed analyses at the country as well as sectoral level are required.

To this end, in this paper we focus on the effects of the North-South trade expansion, changing patterns of trade and the resulting structural transformation in production structures on manufacturing employment, and in particular, on women's employment. We use a larger data set compared to previous studies both in terms of the number of countries (we cover a set of developed (OECD-High Income (HI)) and developing (OECD-Middle Income (MI)) and Other Developing (ODCs)), countries in terms of sectoral structure, and trade partners). A rich set of sector-level data is compiled for 30 reporter countries (21 OECD and 9 non-OECD developing countries) for the periods 1995-99 and 2000-06 ${ }^{1}$. Analyses for each of the 30 reporter countries are conducted taking four different trade partner country groups into account: China, OECD-HI (North), OECD-MI (South), and ODCs (South). To analyze the effects of changes in the structure of production and trade on total employment in general and female employment in particular, we employed two different but complementary methods: i) the structural decomposition analysis (SDA), and ii) the factor-content analysis (FCA) of trade.

The SDA enables us to break down over time the change in women's employment share into two main factors: inter-sectoral shifts in production and employment patterns in the manufacturing industry; and within-sector changes in employment/female employment demand. Schultz (1990) identifies such decomposition exercises to be useful if the sources of the change can be identified, that is, in terms of origins of change and their economic and social consequences. In our case, different levels of export orientation, stage of development and specialization in global division of labor etc. are likely to have effects in terms of shifts from one sector to the other (i.e. from low technology to high technology). Therefore a major source of shift arises from these inter-sectoral shifts of production activity and employment, and the

\footnotetext{
${ }^{1}$ For 30 countries, the number of employees, value of output (USD), and number of female employees data come from 23 ISIC Rev.3 manufacturing industry statistics at 2-digit level of the UN-INDSTAT database. In cases where data on female employment were absent, we referred to the EUROSTAT database. We have used UNCOMTRADE database on SITC Rev.3 value of country exports (USD) and imports (USD), and GTAP database on ISIC Rev.3 manufacturing input-output coefficients. Data from different sources are harmonized using commodityindustry conversion tables. To the best of our knowledge there is no other study in the literature that provides both the sectoral and country-level employment impacts with a comprehensive list of countries for the period after mid1990s.
} 
remaining shift is linked to the "within" component.

In order to shed some light on the total/female employment effects of trade, and for comparability we follow the literature and calculate the changes in factor content resulting from changes in the structure of international trade at country and sector levels. The FCA allows us to estimate the change in employment calculated by taking the difference between actual size of employment, and the hypothetical size that would have been, assuming trade propensities stayed the same over the period of analysis. It is also possible to identify whether there is any gender bias in employment effects of trade using the factor content method. All these calculations are carried out by breaking up "total trade" by trade partners, which also allows one to see different sources underlying the net employment impact of total trade.

SDA results show that the restructuring in manufacturing production captured by the shifts across sectors has a net negative impact on women's employment. This net impact, when analyzed at the sector level, illustrates how the strong influence of traditional sectors (manufacturing of food, textiles and clothing) dominated by female labor is again prevalent over the period of analysis. Similarly, FCA results obtained present a net negative impact of trade on manufacturing employment over the period of analysis (among the 30 countries covered, positive outcome is observed in 17 countries, whereas negative effect is found in 13 of them). In all countries except for the Philippines and the Republic of Korea, rising trade with China results in employment losses. Negative effects from rising trade with China are quite strong in the South, yet positive impact of trade between the reporting country and OECD-HI group can offset this negative impact, ending with a positive change in employment. At the sector level, when employment losses were observed due to trade transformation, this impact was observed in almost all sectors. This evidence supports Kucera and Milberg's (2003) findings; there is no case that some sectors are winners while some are losing. Women's employment outcomes follow the same direction as total employment results.

This paper contains six sections. Section 2 reviews the findings and the theoretical arguments provided by previous research in the literature. Section 3 summarizes the changes in manufacturing trade and employment over 1995-2006 with a brief discussion on the expected outcomes of these changes for employment. Section 4 presents decomposition technique and results obtained. The factor content analysis and its results are discussed in section 5. Finally, the conclusion ends with a discussion of implications of our findings. 


\section{A SYNOPSIS ON CHANGING TRADE PATTERNS AND FEMALE EMPLOYMENT}

There has been a great deal of research in the literature discussing the employment outcomes of international trade focusing mainly on the manufacturing trade and its employment effects. On one hand, it is argued that the end result of such transformation is that both developing and developed countries include more and better employment than alternative employment as workers shift out of agriculture and into waged employment in the expanding manufacturing and services sectors (Joekes and Weston, 1994). On the other hand, flexible employment patterns and informalization in certain sectors of the economy have often been associated with increased trade relations and global competition (Goldberg and Pavcnik, 2003 and 2004; Standing, 1999; Attanasio, et al., 2004; Elson, 1996 and 1999).

It has been pointed out by many that, with increased exports and flexibilization in labor markets, female labor force participation has increased in developing countries (Pearson, 1998). Cagatay and Ozler (1995) also show that female share of labor force rises with export orientation. Feminization of labor force when export industry specializes in low-skilled labor; risk of deterioration in work conditions for women in export industry; risk of downward harmonization of labor standards, particularly related to women's employment; and gender biased occupational segregation are listed as gender impacts of trade (Cagatay, 1996; Ghosh, 1996). Parallel to the flexibilization in the formal sector, informal working conditions have become widespread with rising competition due to trade by cutting wages. Carr, et al. (2000) emphasize an uneven distribution of gains from trade particularly for home-based workers, a majority of whom are women. They analyze the issue as a part of global value chains of goods traded. Studies have also been done on trade impacts on women's employment in developed countries. Some argued that there has been no decline in women's share in manufacturing employment since women whose wages are lower were hired to replace men due to rising competition. Others going beyond employment records checked the welfare impacts of trade. Case studies on Japan and Taiwan provided evidence for declining wages both for men and women, more so for women in Japan (Yamamoto, 2000), whereas the reverse was true in Taiwan, where the gender wage gap was decreasing due to an export-led growth strategy, as well asa stronger decline in men's wages than women's wages (Berik, 2000). Depending on the country's development status, the agents that identify global division of labor and foreign trade 
relations change from region to region, from country to country and from sector to sector, and what's more, these agents work differently with regards to male versus female labor demand, payments to labor, work conditions and welfare effects. A comprehensive discussion on all these issues, and providing recent evidence, can be found in the edited book titled "Trade and Employment from Myths to Facts," published by ILO (2011).

Theoretically, employment outcomes of international trade vary depending on whether trade leads to growth or contraction in production at the sectoral or macro level. In a simple demand-constrained economy, it is possible to see some direct relations among trade growth and labor productivity, as when growth brings rise in labor productivity with trade, and employment would decline with a lower output labor coefficient (Gibson, 2011). Thus, whether productivity outcome of trade is negative or positive is a prior determining relationship to look at in exploring the employment outcomes of trade. Furthermore, potential wage impact of international trade could affect employment outcomes as a key factor to control.

According to Heckcher-Ohlin-Samuelson (HOS) theorem, trade induces demand for the abundant factor as production and exports are specialized in sectors that use the abundant factor. If relatively unskilled labor is the abundant factor, which is more the case in the South, the predicted outcome of this theory is higher demand for unskilled labor in South while the opposite is expected in the North. If the unskilled labor pool comprises women, , then HOS theory points to a rise/decline in demand for female labor in the South/North. On the other hand, if trade induces skill premia and leads to a relocation of skilled labor from non-tradable to tradable sectors, consistent with skill-biased technical change argument, trade is found to promote demand for skilled labor despite being the scarce factor.

Theoretical arguments for women's employment outcomes of trade emphasize four different mechanisms that lead to a change in female intensity of employment (Isaza-Castro, 2012). The first assumes female and male labor are imperfect substitutes and thus, increasing exports, or rising competition with imported goods have potential to change employment composition, particularly if women are concentrated in sectors more exposed to trade. The "necessity" for nimble fingers in the electronic industry in Asia (Elson and Pearson, 1981), and requirements such as combinations of organizational, technical and communication skills illustrate the cases where female and male labor are imperfect substitutes where trade induces higher demand for female labor. The second is built on the assumption that technology and female labor could be complementary inputs. If expansion of trade increases capital intensity 
and if the new technology promotes employment opportunities which require less physical strength, then female intensity of labor could increase with trade. With a change in the relative price of imported technology and capital goods, through trade, the share of women's employment could be changed in a positive or negative direction depending on the type of new technology. The third is based on the Beckerian explanation of discrimination against women, where it is argued that trade expansion increases competition, which leads to a change in employment composition where female intensity rises with competition (Becker, 1971; Black and Brainerd, 2004). The competition becomes more severe via the increase in imported goods and services, which in turn curbs discrimination against women given that gender discrimination is costly, i.e. discrimination cost here is the higher wage payment, which is higher than the marginal revenue product of male labor. The employment outcome of trade expansion predicted by Becker's theory is that rising competition puts pressure on firms and does not allow them to pay for higher wage for male workers and thus demand for female labor is induced by intensified competition.

The last argument points to the cost-cutting strategies of firms with rising competition, which would influence bargaining power of labor, through which employment composition changes, unlike in the Beckerian view (Albelda, et al. 2004). Berik, et al. (2004) find a positive relationship between the gender wage gap and rising competition in Korea and Taiwan, which supports the argument that expansion of trade, which increases competition, induces demand for female labor with lower wages. Higher competition weakens the bargaining power of labor in tradable sectors, which changes the employment composition.

With this background, next we present our methodology and findings on manufacturing employment effects of North-South trade expansion over the recent period. Then we discuss our results comparing them with earlier findings obtained by using similar methodologies.

\section{TRADE FLOWS AND EMPLOYMENT OUTCOMES -RECENT TRENDS}

Figure 1 shows the general picture of different country groups\%/countries' shares in world exports since 1990. The outstanding rise in China's share in world exports is apparent. From 1990 to 2006 export share of China increases from 1.9 to 15.4 percent. We also observe a continuous rise in South's (OECD-MI plus ODCs ${ }^{2}$ ) export share from 2.6 to 8.6 with a declining

\footnotetext{
${ }^{2}$ North-South trade is in general empirical literature approximated by trade between OECD and non-OECD
} 
trend in exports of the North (OECD-HI) over the recent two decades (decreasing from 72.7 to 50.7 percent of world exports). Taking into account the higher labor intensity of exported goods from the South, a rise in manufacturing employment can be expected in the South, whereas manufacturing employment may continue to decline in the North, prolonging the trends of 1990s.

Figure 1. Share in world exports $(\%)$

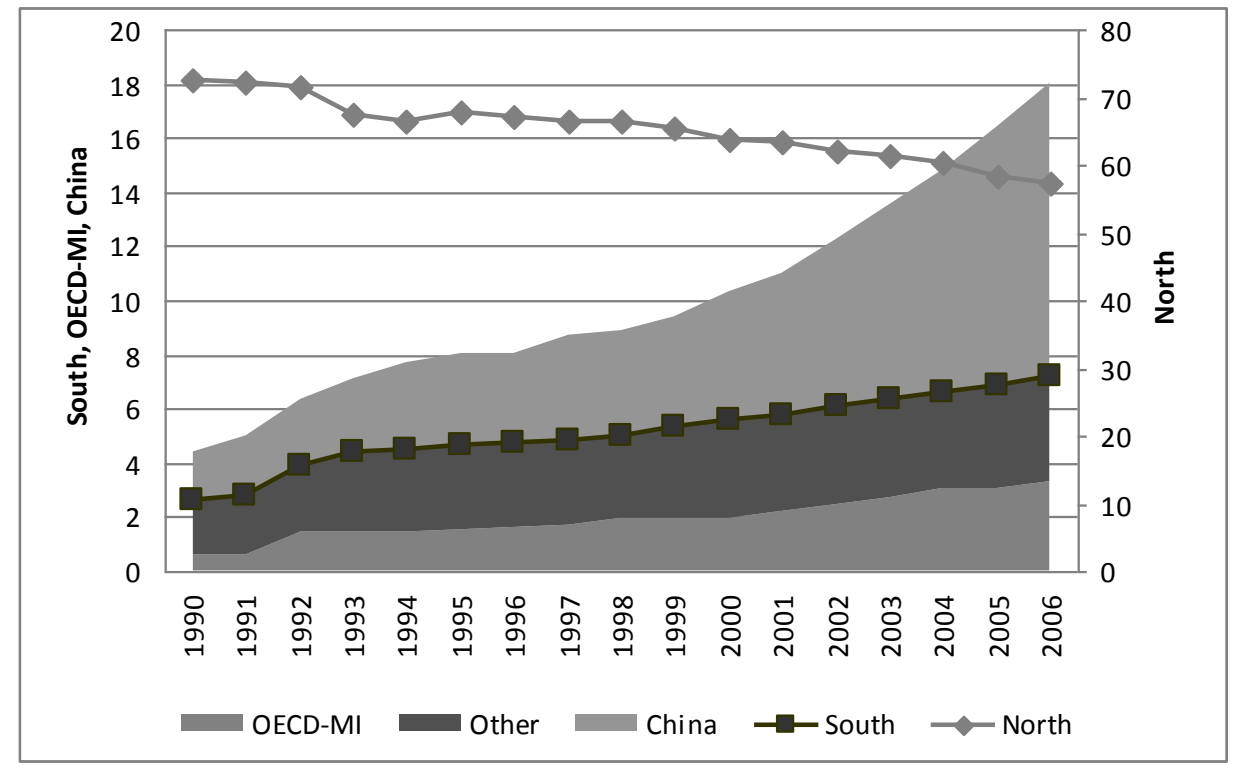

Source: WTO Statistics Database

Export-output/supply ratios present supporting evidence for the major rise in South's share of world exports. The figures show a relatively more stable picture over the period for OECD-HI countries. But within the group there are countries like Austria, Denmark, Germany, and Netherlands, which illustrate significant rises in export-output and export-supply ratios. In OECD-MI and ODCs we observe large increases in export-output ratios. Slovenia, Czech Republic, Slovak Republic, Romania and Jordan are cases in point. Even if imports are taken into account, we observe that export-supply ratios present positive changes at high degrees for these countries. Based on the conjecture that South's exports are more labor intensive than that of North, the figures in Table 1 indicate possible employment gains in the South due to trade expansion, whereas the opposite could be expected in the North, particularly in countries where we see stagnant figures for export-output and export-supply ratios.

countries. However in this study in order to mimic North-South trade we included considered middle income OECD countries together with non-OECD countries in South as there are major differences between middle income OECD countries significantly differ from and high income OECD countries. 
Table 1. Country-level total manufacturing exports-output and exports-supply ratios

\begin{tabular}{|c|c|c|c|c|c|c|c|c|c|}
\hline \multirow[b]{2}{*}{ OECD-HI } & \multicolumn{2}{|c|}{ Export/Output } & \multicolumn{2}{|c|}{ Export/Supply } & \multirow[b]{2}{*}{$O E C D-M I$} & \multicolumn{2}{|c|}{ Export/Output } & \multicolumn{2}{|c|}{ Export/Supply } \\
\hline & $1995-9$ & $2000-6$ & $1995-9$ & $2000-6$ & & $1995-9$ & $2000-6$ & $1995-9$ & $2000-6$ \\
\hline Austria & 43 & 54 & 29 & 35 & Czech Rep. & 40 & 52 & 28 & 35 \\
\hline Denmark & 34 & 41 & 24 & 28 & Hungary & 50 & 62 & 32 & 39 \\
\hline Finland & 36 & 36 & 29 & 28 & Slovak Rep. & 57 & 69 & 37 & 42 \\
\hline France & 23 & 26 & 19 & 20 & Slovenia & 34 & 53 & 25 & 34 \\
\hline Germany & 28 & 36 & 23 & 29 & Turkey & 17 & 20 & 13 & 15 \\
\hline Greece & 22 & 15 & 13 & 10 & Average & 35 & 45 & 31 & 35 \\
\hline Ireland & 57 & 51 & 40 & 38 & $O D C s$ & $1995-9$ & $2000-6$ & $1995-9$ & $2000-6$ \\
\hline Italy & 24 & 25 & 21 & 21 & Bulgaria & 39 & 37 & 28 & 23 \\
\hline Japan & 12 & 15 & 11 & 14 & India & 11 & 12 & 10 & 11 \\
\hline Rep.of Korea & 21 & 24 & 18 & 21 & Indonesia & 19 & 17 & 18 & 16 \\
\hline Netherlands & 47 & 58 & 31 & 37 & Jordan & 10 & 23 & 6 & 14 \\
\hline Portugal & 26 & 31 & 19 & 21 & Kazakhstan & 26 & 38 & 21 & 21 \\
\hline Spain & 23 & 24 & 18 & 18 & Lithuania & 45 & 45 & 25 & 26 \\
\hline Sweden & 38 & 43 & 29 & 32 & Philippines & 48 & 62 & 31 & 37 \\
\hline UK & 26 & 29 & 20 & 21 & Romania & 22 & 37 & 18 & 24 \\
\hline US & 12 & 12 & 10 & 10 & Thailand & 31 & 37 & 22 & 27 \\
\hline Average & 30 & 33 & 22 & 24 & Average & 28 & 36 & 20 & 23 \\
\hline
\end{tabular}

Sources: UN-INDSTAT, UN-COMTRADE and EUROSTAT

Note: Supply $=$ Output + Imports

In order to get a more elaborate picture of the potential employment outcomes of the changes stated above, we continue our analysis at the sectoral level. For a description of the sectors, we use the sectors' shares in total manufacturing value-added, total manufacturing exports and imports, as well as the female share of employment, which also reflects labor intensity in each sector. At the outset we find that each sector's shares in total manufacturing exports and imports are very close to each other and appear more stable over the period in OECD-HI group. The differences in shares rise for OECD-MI particularly in manufacturing of machinery and equipment, electrical machinery $\left(29+30+31^{3}\right)$ (Table 2). These sectors correspond to higher share in imports compared to exports of the OECD-MI countries. In ODCs we see even more divergence between import and export shares of these sectors, as well as in manufacturing of printing equipment $(21+22)$.

Sector shares in manufacturing value added and in manufacturing exports also suggest (negative) employment outcomes in OECD-HI countries. Only five out of 23 sectors

\footnotetext{
${ }^{3}$ ISIC-Rev 3 classification of the manufacturing sectors is presented in Table A1 in the Appendix.
} 
(manufacture of chemical, petroleum products $(24+25)$, motor vehicles (34)), office equipment, TV and communications $(30+32)$ present a rise over the period both in terms of their shares in total manufacturing value added and in manufacturing exports (Table 2). Despite the positive changes recorded in the female share of employment in the North in certain sectors, the size of the change appears to be limited where the overall average decreases slightly. Negative trend in total manufacturing value added as well as exports in more labor intensive with higher shares of female employment can be indicative for this outcome.

In the South, the OECD-MI countries differ from ODCs and present a more similar picture to OECD-HI countries with respect to sectoral shares of manufacturing value added. Sectors list according to the intensity of female employment shows more similarity between OECD-HI and OECD-MI groups, as well. Although the number of sectors that present positive changes in value added and export shares is higher, we observe that the sectors with high female shares have lost their shares in total manufacturing over the period in OECD-MI group similar to high income group of countries. This could be one of the explanations behind the declining shares of female employment for the overall average of this group.

Unlike the other two groups, in ODCs the manufacturing of textiles, wearing apparel and leather products (17, 18 and 19) still composes a significant portion of exports in total manufacturing, even though the shares of these sectors in value added are very low. However, unexpectedly, we again observe a declining trend in female share of employment almost in all sectors independent of whether there has been an increase or decrease in the sector's weight in total manufacturing value added/exports (except for 23 and 20). In the South, we observe a large negative change in female employment share, i.e. decline in OECD-MI countries, which suggests that OECD-MI countries face with the issue experienced by the North after a decade's time. In ODCs, we do not see any rise in female share of employment, which contrasts in fact, with the findings for the South in earlier studies based on the data for the 1980s and 1990s.

Table 2. Sector shares in manufacturing value added, shares in manufacturing exports and female employment shares by sector

\begin{tabular}{rrrrrrrrr}
\hline & $\begin{array}{c}\text { Share in total } \\
\text { manufacturing value- } \\
\text { added (\%) }\end{array}$ & \multicolumn{2}{c}{$\begin{array}{c}\text { Share in total } \\
\text { manufacturing } \\
\text { exports (\%) }\end{array}$} & $\begin{array}{c}\text { Share in total } \\
\text { manufacturing } \\
\text { imports (\%) }\end{array}$ & $\begin{array}{c}\text { Share of female } \\
\text { employment in each } \\
\text { sector (\%) }\end{array}$ \\
\hline OECD-HI & $1995-9$ & $2000-6$ & $1995-9$ & $2000-6$ & $1995-9$ & $2000-6$ & $1995-9$ & $2000-6$ \\
\hline 23 & 3.5 & 3.9 & 0.5 & 0.3 & 0.8 & 0.7 & 5.1 & 2.9 \\
35 & 2.2 & 2.4 & 2.9 & 2.9 & 2.3 & 2.7 & 5.3 & 6.8
\end{tabular}




\begin{tabular}{|c|c|c|c|c|c|c|c|c|}
\hline 27 & 4.6 & 4.8 & 6.5 & 6.4 & 7.6 & 7.3 & 7.3 & 7.6 \\
\hline 34 & 7.5 & 8.3 & 12.7 & 13.8 & 13 & 13.7 & 11.5 & 12.4 \\
\hline 20 & 2.5 & 2.4 & 1.1 & 1.1 & 1.1 & 1 & 14 & 13.4 \\
\hline 28 & 5.5 & 5.9 & 2.7 & 2.7 & 2.4 & 2.6 & 15.3 & 15.7 \\
\hline 26 & 3.7 & 3.5 & 2 & 1.7 & 1.6 & 1.5 & 16.2 & 18.3 \\
\hline $29+31+33$ & 13.4 & 13.4 & 18.1 & 18.7 & 18.4 & 17.8 & 21.9 & 22.6 \\
\hline $36+37$ & 2.9 & 2.9 & 2.5 & 2.3 & 2.8 & 2.9 & 25.8 & 26.4 \\
\hline $24+25$ & 11.8 & 12 & 13.8 & 16.9 & 15.4 & 16.4 & 30 & 31.7 \\
\hline $21+22$ & 8.6 & 8.2 & 5.3 & 4.2 & 3.6 & 3 & 30.7 & 28.5 \\
\hline $30+32$ & 7.3 & 6.6 & 14.3 & 14.7 & 14.9 & 15.9 & 30.8 & 32.3 \\
\hline $15+16$ & 15.3 & 12.8 & 7.4 & 6.8 & 7.5 & 6.7 & 38.3 & 39.8 \\
\hline 19 & 1 & 0.7 & 1.9 & 1.5 & 1.7 & 1.5 & 42.8 & 41.9 \\
\hline 17 & 2.9 & 1.9 & 4.8 & 3.5 & 3.8 & 3.2 & 48.7 & 44.5 \\
\hline 18 & 1.9 & 1.3 & 3.4 & 2.4 & 3.2 & 3 & 71.4 & 72.3 \\
\hline Average & 5.9 & 5.7 & 6.2 & 6.2 & 6.3 & 6.2 & 28.5 & 28.2 \\
\hline$O E C D-M I$ & $1995-9$ & $2000-6$ & $1995-9$ & $2000-6$ & $1995-9$ & $2000-6$ & $1995-9$ & $2000-6$ \\
\hline 23 & 3 & 2.6 & 0.5 & 0.2 & 1.1 & 0.6 & 12 & 9.8 \\
\hline 35 & 0.7 & 0.8 & 1.4 & 1.2 & 1.3 & 1 & 15.4 & 6.9 \\
\hline 27 & 7 & 6.5 & 10.7 & 8.4 & 8 & 8.8 & 23 & 18.1 \\
\hline 20 & 2.2 & 2 & 1.8 & 1.2 & 0.7 & 0.8 & 23.2 & 18.6 \\
\hline 28 & 4 & 5.9 & 3.9 & 3.7 & 3.1 & 3.3 & 24.5 & 18.9 \\
\hline 34 & 6.1 & 8.6 & 12.9 & 19.6 & 12.9 & 15.4 & 28.4 & 28.6 \\
\hline $29+31+33$ & 11.1 & 14 & 16 & 17.7 & 22.3 & 20.7 & 33.7 & 34.1 \\
\hline $36+37$ & 2.7 & 3.1 & 3.1 & 3.5 & 1.9 & 1.8 & 34.3 & 30.1 \\
\hline 26 & 4 & 3.8 & 3.4 & 2.5 & 1.9 & 1.8 & 35.4 & 32.3 \\
\hline $24+25$ & 10.5 & 9.3 & 11.8 & 11 & 17.4 & 17.2 & 37.9 & 38.5 \\
\hline $21+22$ & 5.5 & 4.8 & 3.1 & 2.5 & 3.5 & 2.9 & 45.8 & 44.2 \\
\hline $15+16$ & 14.2 & 10.2 & 6.6 & 5.1 & 8.3 & 7.7 & 47.3 & 44.2 \\
\hline $30+32$ & 3.3 & 6.6 & 7 & 12.3 & 9.9 & 12.1 & 49.2 & 49.5 \\
\hline 19 & 1.2 & 0.8 & 2 & 1.1 & 1.6 & 1.2 & 67.3 & 68.1 \\
\hline 17 & 4.2 & 3.7 & 8 & 5.9 & 4.4 & 3.5 & 69.9 & 69.4 \\
\hline 18 & 2.2 & 2.3 & 7.7 & 4.1 & 1.6 & 1.1 & 86.9 & 88 \\
\hline Average & 5.1 & 5.3 & 6.2 & 6.3 & 6.2 & 6.2 & 45.4 & 39 \\
\hline
\end{tabular}

\begin{tabular}{rrrrrrrrr} 
ODCs & $1995-9$ & $2000-6$ & $1995-9$ & $2000-6$ & $1995-9$ & $2000-6$ & $1995-9$ & $2000-6$ \\
\hline 27 & 9.1 & 10.8 & 17.9 & 16.3 & 13.9 & 13.4 & 18.4 & 17.6 \\
23 & 9.1 & 10.1 & 0.8 & 1.5 & 2 & 0.9 & 20.8 & 20.9 \\
28 & 2.6 & 3.4 & 1.6 & 1.8 & 4.2 & 3.2 & 21.7 & 19.4 \\
35 & 3 & 3.8 & 2.3 & 4 & 9.2 & 11.5 & 23.4 & 19.1 \\
34 & 1.6 & 1.8 & 2.7 & 2.1 & 3.6 & 3.1 & 23.4 & 15.7 \\
20 & 1.9 & 2.1 & 2.6 & 2.4 & 0.8 & 1 & 24.1 & 22.7
\end{tabular}




\begin{tabular}{rrrrrrrrr}
26 & 3.9 & 4.5 & 1.9 & 1.4 & 2 & 1.7 & 25.7 & 23.3 \\
$36+37$ & 2.3 & 2.9 & 7.5 & 6.9 & 1.7 & 1.9 & 33.4 & 31 \\
$21+22$ & 6.1 & 7 & 8.7 & 11 & 31.1 & 22.3 & 34 & 33 \\
$24+25$ & 13.7 & 12.4 & 16.9 & 14 & 26.3 & 21.2 & 34.7 & 33.4 \\
$29+31+33$ & 3.6 & 3.8 & 2.5 & 1.8 & 4.2 & 3.1 & 35.3 & 34.9 \\
$15+16$ & 21.9 & 18.8 & 9.3 & 8.3 & 15.7 & 8.8 & 41.3 & 40 \\
$30+32$ & 4.8 & 6.2 & 16.5 & 17.8 & 14.6 & 17.6 & 49.7 & 47.2 \\
17 & 5.2 & 3.8 & 8 & 7.4 & 6.7 & 4.9 & 55 & 52.9 \\
19 & 1.3 & 0.9 & 4.3 & 3.5 & 2.1 & 1.3 & 59.4 & 56.1 \\
18 & 3.3 & 3.1 & 10.3 & 12.9 & 1 & 1.1 & 73.8 & 75.2 \\
Average & $\mathbf{5 . 8}$ & $\mathbf{6 . 0}$ & $\mathbf{7 . 1}$ & $\mathbf{7 . 1}$ & $\mathbf{8 . 7}$ & $\mathbf{7 . 3}$ & $\mathbf{3 9 . 5}$ & $\mathbf{3 9 . 6}$ \\
\hline
\end{tabular}

Sources: UN-INDSTAT, UN-COMTRADE and EUROSTAT

Note: The industries are sorted from least to highest shares of female labor for each group of countries. Data on share of female in employment do not include Turkey as the figures for the 2000s are not available.

The export-supply (X/S) and export-output (X/O) ratios at the sector level provide additional information about the significance of each sector in different country groups' trade structure. As presented in Table 3, export-supply ratios of all sectors show more moderate changes over the period in OECD-HI country group when compared to the other two groups. In Table 2 we show that female share of employment declined in the majority of the sectors in other developing countries. We now emphasize that we observe this outcome despite the fact that female labor intensive sectors' export-supply ratios show positive changes in these countries. On the other hand, for OECD-MI countries, we observe the opposite, which may partly be due to declining export-output ratios but also this may indicate rising trends in imports in these countries. It is also interesting to observe that in OECD-HI countries, among the female labor intensive sectors, there are sectors where female share of employment declines, even when we observe a major rise in export-output ratio, the manufacture of leather products (19) is as such. 
Table 3. Export-output and export-supply shares by sector

\begin{tabular}{|c|c|c|c|c|c|c|c|c|c|c|c|c|}
\hline & \multicolumn{4}{|c|}{$O E C D-H I$} & \multicolumn{4}{|c|}{$O E C D-M I$} & \multicolumn{4}{|c|}{$O D C s$} \\
\hline & \multicolumn{2}{|c|}{$\mathrm{X} / \mathrm{O}$} & \multicolumn{2}{|c|}{$\mathrm{X} / \mathrm{S}$} & \multicolumn{2}{|c|}{$\mathrm{X} / \mathrm{O}$} & \multicolumn{2}{|c|}{$\mathrm{X} / \mathrm{S}$} & \multicolumn{2}{|c|}{$\mathrm{X} / \mathrm{O}$} & \multicolumn{2}{|c|}{$\mathrm{X} / \mathrm{S}$} \\
\hline & 1995-9 & 2000-6 & $1995-9$ & $2000-6$ & $1995-9$ & $2000-6$ & $1995-9$ & $2000-6$ & 1995-9 & 2000-6 & $1995-9$ & 2000-6 \\
\hline $15+16$ & 15 & 19 & 13 & 16 & 18 & 25 & 17 & 20 & 12 & 12 & 10 & 11 \\
\hline 17 & 89 & 70 & 30 & 31 & 103 & 81 & 51 & 52 & 36 & 65 & 23 & 29 \\
\hline 18 & 59 & 108 & 25 & 26 & 94 & 68 & 117 & 72 & 74 & 101 & 67 & 86 \\
\hline 19 & 72 & 380 & 28 & 33 & 66 & 75 & 51 & 48 & 74 & 199 & 49 & 84 \\
\hline 20 & 11 & 12 & 9 & 10 & 27 & 28 & 28 & 26 & 29 & 30 & 24 & 24 \\
\hline $21+22$ & 18 & 16 & 15 & 14 & 21 & 25 & 19 & 21 & 13 & 10 & 10 & 8 \\
\hline 23 & 5 & 4 & 13 & 10 & 6 & 6 & 24 & 16 & 68 & 29 & 18 & 21 \\
\hline $24+25$ & 43 & 53 & 27 & 32 & 45 & 56 & 34 & 37 & 30 & 33 & 18 & 18 \\
\hline 26 & 15 & 15 & 13 & 13 & 30 & 36 & 30 & 29 & 12 & 11 & 28 & 11 \\
\hline 27 & 48 & 51 & 26 & 28 & 61 & 60 & 46 & 44 & 76 & 78 & 30 & 25 \\
\hline 28 & 17 & 19 & 13 & 14 & 46 & 33 & 36 & 30 & 20 & 17 & 12 & 12 \\
\hline $29+31+33$ & 39 & 48 & 26 & 31 & 53 & 58 & 37 & 41 & 46 & 57 & 17 & 24 \\
\hline $30+32$ & 96 & 136 & 34 & 39 & 70 & 86 & 44 & 54 & 79 & 90 & 31 & 35 \\
\hline 34 & 53 & 68 & 26 & 29 & 102 & 146 & 71 & 79 & 278 & 108 & 10 & 15 \\
\hline 35 & 84 & 48 & 29 & 29 & 64 & 61 & 48 & 47 & 6831 & 63 & 23 & 24 \\
\hline $36+37$ & 26 & 26 & 19 & 18 & 39 & 50 & 37 & 42 & 62 & 63 & 53 & 51 \\
\hline Totals & 30 & 33 & 22 & 24 & 35 & 45 & 31 & 35 & 28 & 34 & 20 & 22 \\
\hline
\end{tabular}

Source: UN-INDSTAT, UN-COMTRADE and EUROSTAT

We believe that without an analysis of the import trends, the changes in the share of countries in world exports cannot provide a complete picture of total trade expansion over the period. Import penetration rates provide additional measures of trade expansion. ${ }^{4}$ Table 4 presents period averages of import penetration rates for country groups in the 1990s and 2000s. Both in the North and the South, North import penetration rates are higher than those in the South. However, the percentage changes show that import penetration increased immensely both in the South and the North for South's manufacturing goods. This is mainly due to the imports of OECD-MI group. In the case of the North, considering that imports from the South are more labor intensive than that of North, figures in Table 3 point to employment losses in the North again. However, it is not possible to adopt a similar expectation for the South countries.

\footnotetext{
${ }^{4}$ Import penetration rate is calculated as the ratio of imports to domestic demand and indicates importance of foreign goods in the domestic market.
} 
Compared to the 1990s, in the 2000s, penetration rates of imports from the South are considerably higher for the South, as well. Expected employment outcomes of South-South trade could be negative or positive first, depending on the relative labor intensities of traded goods from the country group of their own. Additionally, it would not only depend on the relative employment effect of imports from South but also the employment effects of their exports to the North. On the other hand China's import penetration rates show a major leap both in the North and the South. Such an observation may indicate significant employment effects of imports from China. Over the period we observe a major increase in China's import penetration rate in Northern markets, reaching to a level higher than that of OECD-MI countries in total. Strong China effect can also be seen in the South countries. Negative incidence of these losses on total employment depends on the expansion of their exports to the North. Their exports may not increase at high rates as before, as China has become a major exporter for all counties.

Starting with the economic reforms in 1978, China's rapid trade liberalization since the mid-1990's and eventual accession to the WTO in 2001 have raised concerns of her increased export competition in international markets, particularly among those developing countries dependent on labor-intensive products in exports (Shafaeddin, 2004). Although concerns about China's competitive power have been widespread, neighboring Asian countries have been most vulnerable to increased competition due to their close geographical proximity to China, their similar stages of development, and similar relative factor endowments and production costs (Lall and Albaladejo, 2004; Greenaway, et al., 2008). Using a gravity model, Greenaway et al. show that for the 1990s and early 2000s, the negative impact of China on other Asian countries' exports has been growing over time and larger in industrialized country markets. Moreover, Greenway et al. find that China's export growth has displaced more advanced Asian country exports rather than low and middle income Asian country exports. In an econometric study of Chinese vs. ASEAN exports, Holst and Weiss (2004) argue that for the late 1990s, due to increased Chinese export competition, ASEAN economies have experienced a loss of market share in USA and Japanese markets, especially for the export activities that they specialize in. Holst and Weiss point out that for electronics, electricals and engineering, all ASEAN countries show a consistent decline in competitiveness in both USA and Japanese markets, while for the categories of primary products, resource-based manufactures, and textiles and garments, all ASEAN countries show significant losses in either market. On the other hand, for the period 1992-2005, Athukurala (2009) demonstrates that China's integration into global networks of 
vertically integrated industries as a major assembly center has in fact created new opportunities for the other East Asian countries to specialize in parts and components production and assembly. Furthermore, Athukurala indicates that China's increased penetration into international markets in traditional labor-intensive manufactured goods has crowded out exports of high-wage East Asian NIEs, which have been already losing comparative advantage in such products.

Table 4. Import-output ratios and import penetration rates

\begin{tabular}{lrrrrrr}
\hline & \multicolumn{3}{c}{ North } & \multicolumn{3}{c}{ South } \\
\cline { 2 - 7 } Country of Origin & $1990 \mathrm{~s}$ & $2000 \mathrm{~s}$ & \% Change & $1990 \mathrm{~s}$ & $2000 \mathrm{~s}$ & \% Change \\
\hline China & 0.8 & 2.2 & 176 & 0.7 & 2.9 & 292 \\
North & 25.9 & 26.3 & 2 & 26.5 & 30.9 & 17 \\
South & 3.5 & 4.9 & 38 & 9.3 & 12.3 & 32 \\
$\quad$ OECD Middle Income & 1.2 & 2.1 & 85 & 3.4 & 4.8 & 44 \\
$\quad$ OtherDeveloping & 2.4 & 2.8 & 15 & 6.0 & 7.5 & 25 \\
All & 30.2 & 33.4 & 11 & 36.6 & 46.2 & 26 \\
\hline
\end{tabular}

Source: WTO Statistics Database and UN-INDSTAT, UN-COMTRADE and EUROSTAT

Note: Import penetration rate $=$ Imports/(Output + Imports-Exports $)$

Country level results present how the significance of imports from different regions changes over time for each country. Again we observe that in all countries OECD-HI countries' import penetration rates are higher than the other groups, yet, China's import penetration rates show the highest changes over the period ${ }^{5}$ (Table A2 in Appendix). Similarly, imports from China majorly affect the OECD-MI ${ }^{6}$ and ODCs as well. When the import penetration rates are analyzed by sector, among the high income OECD countries, not surprisingly, China's import penetration rates are very high in more traditional labor intensive and female labor intensive sectors (17, 18 and 19). However, in recent years, we also observe a big change in

5 Among the OECD-HI, the countries with higher rates than the group average are the United Kingdom, Netherlands, Sweden, Finland and Ireland. We also see large increases in OECD-MI as well as other developing countries' import penetration rates in these countries; however, China by itself lists higher rates than OECD-MI countries as a group. Figures for the North show declines particularly in the case of Finland, Ireland, Greece and Republic of Korea. The changes in China's import penetration rates seem much larger in this group except for Portugal and Spain. Change in the imports from OECD-MI countries also record higher rates in these countries compared to China. We see that there is a stronger rise in import penetration rates of OECD-MI countries in the North larger than that of China.

${ }^{6}$ Among OECD-MI, Slovenia and Czech Republic present highest China impact (Table A2 in Appendix). Other developing countries' import penetration rates also rise significantly for this group. Turkey singles out among the group with a lower change in China's import penetration rate than OECD-MI countries. Among all, Indonesia and Philippines appear with the lowest changes in Chinese import penetration rates while Kazakhstan, Lithuania, Bulgaria and Romania present the highest changes. 
manufacturing of furniture and other products $(36+37)$. Similar to China, imports from other developing countries are more concentrated in female labor-intensive sectors. Except for the manufacture of motor vehicles (34), imports from middle income OECD countries in almost all sectors seem to lose significance for OECD-HI countries. Particularly in female labor-intensive sectors, China and ODCs' imports to OECD-HI countries show much higher rates than the middle income OECD. The expected rises in employment in OECD-MI through exports to the North may not be realized as in traditional labor intensive sectors the change may not have happened or at least may have been offset and not been effective on the overall outcome.

The significance of China's effect can also be observed in OECD-MI and ODCs at sector level calculations ${ }^{7}$. Even though the penetration rates of Chinese imports are lower when compared to the high-income OECD group, percent changes over time indicate major changes in their trade structure ${ }^{8}$. In ODCs, unlike the OECD-MI the imports from OECD-HI countries show increases in penetration rates in traditional female intensive sectors, which may indicate rising intra-industry trade or expansion in the internationalization of production in these sectors.

\section{STRUCTURAL DECOMPOSITION}

Aggregate employment and trade data provide some insight into the effects of changes in trade patterns on production and on employment - women's employment in particular. One way to look at the sectoral effects on women's employment is to apply a decomposition analysis. Such analysis can be interpreted as one that captures the changes in the patterns of international trade related to the development process and structural adjustment. The structural decomposition analysis we employ in this section helps us to relate changes in women's share in total employment to two components: the change in the structural composition of production/employment and changes in within-sector employment patterns.

Changes in the structural composition of production/employment represent the effects of shifts in sectoral production/trade on women's employment share. This term is affected if the patterns shift towards sectors which traditionally employ more women tends to expand/contract (sectoral composition of production activity and employment is very much related to trade patterns). Such a shift in production/employment patterns of course is related to the

\footnotetext{
${ }^{7}$ Sector level import penetration rates can be provided upon request.

${ }^{8}$ We observe a declining trend in OECD-HI group's import penetration rates in OECD-MI group in general (except for eight among 23 sectors $(24+25,21+22,15+16,34$ and 27$))$.
} 
transformation of the production structure of the economy and can well be affected by the changing position of the economy in the global division of labor.

Changes in within-sector employment patterns relate changes in women's share in employment to the women's relative participation in the individual sectors, holding the sectoral composition of employment constant. This term can be thought to portray, for instance increased reliance on flexible labor as well as the increased labor force participation of women (with lower wages). ${ }^{9}$ Schultz (1990), in the context of how composition of employment changes with economic development and types of employment held by women in various stages of economic development, emphasizes that sectoral composition of production and employment changes systematically with development, as well as the division of labor in the global trade networks. If so, the trends in women's employment can be explained by inter-sectoral shifts in the distribution of employment and by trend within the sectors. Definitely, changes in the final demands due to changing patterns of trade shall alter the sectoral composition of production and employment, with consequences for the fraction of jobs women are likely to hold.

Schultz (1990) also emphasizes that such decomposition analyses can be useful if the two identified sources of the change can be given meaning in terms of origins of change and its economic and social consequences. So a major source of shift arises from these inter-sectoral shifts of production activity and employment, and is linked to the second component. Sectoral shifts of output $\left(1^{\text {st }}\right.$ Term) can be due to shifts in productivity, relative prices and income elasticity of consumers (tastes), each of which can be associated with the changing patterns of trade. The algebraic description of the decomposition analysis includes the representation of $w_{i}^{j}={ }^{W E_{i}^{j}} T E_{i}^{j}$, women's employment share in country $\mathrm{i}$, sector $\mathrm{j}$ and $s_{i}^{j}=T E_{i}^{j} T E_{i}$, the employment share of sector $\mathrm{j}$ in total employment of country $\mathrm{i}$ and defines women's share in total employment in country $i$ as:

$$
w_{i}=w_{i}^{j} s_{i}^{j}
$$

\footnotetext{
${ }^{9}$ There is also a third term in the decomposition captures the co-variation in the change in the relative structure of sectors and changes in the fraction of women within sector.
} 
Therefore, the change in women's share in total employment in country $i$ can be decomposed as follows:

$$
\Delta w_{i}=w_{j}^{j} \Delta s_{i}^{j}+{ }_{j} \Delta w_{i}^{j} s_{i}^{j}+{ }_{j} \Delta w_{i}^{j} \Delta s_{i}^{j}
$$

Table 5. Decomposition of the change in female share of employment

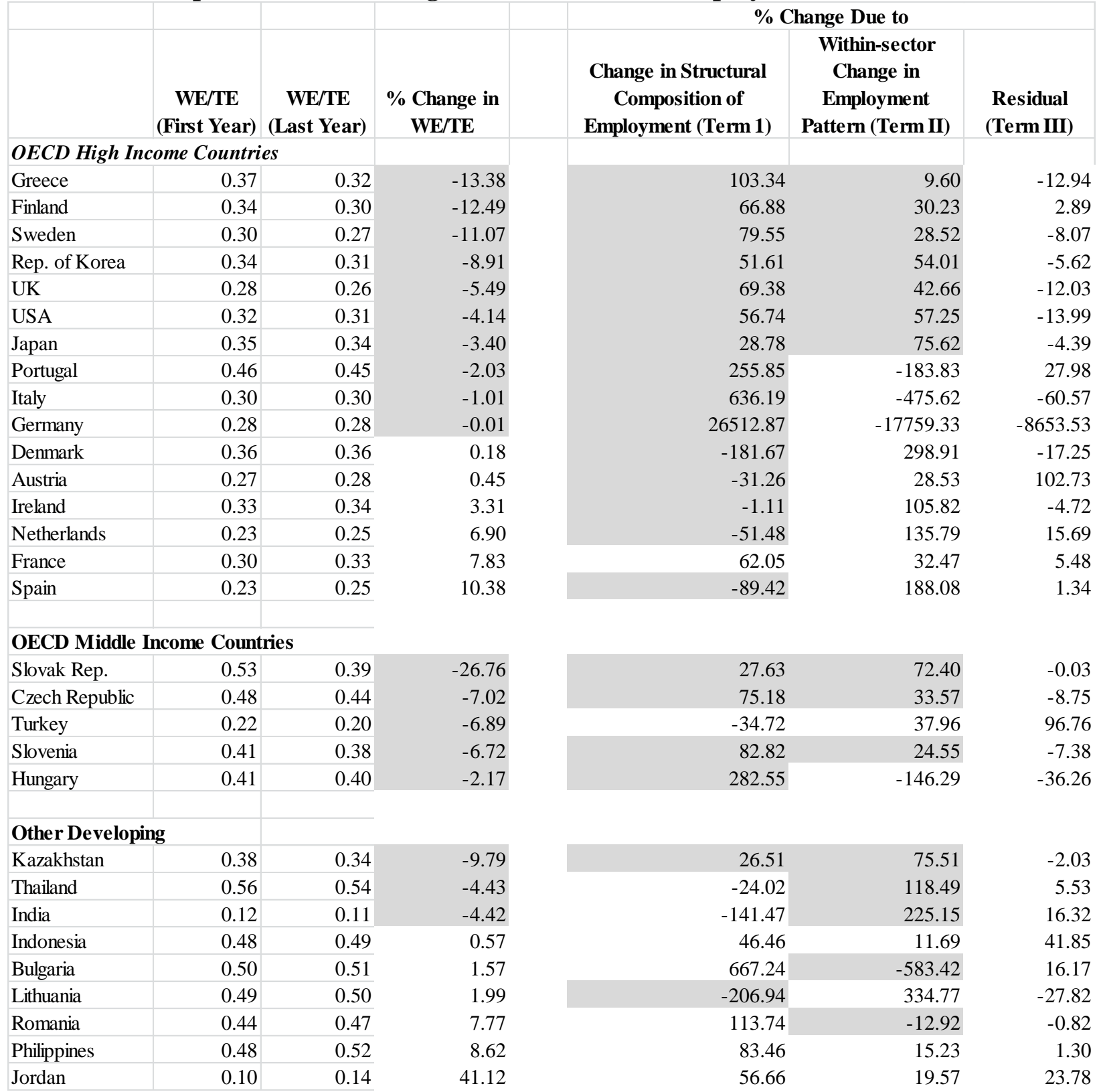

Note: Countries are ordered from ones with lowest (negative) to ones with highest (positive) change in female share of employment in each country group. The signs display the direction of change of the relevant term. 
Table 5 reveals that share of female employment in total employment decreased in most (ten out of 16) of the OECD-HI countries. The decomposition analysis points out that in all the countries that display negative change in the female share, the shift of the production between sectors (Term I) has worked towards a decrease in female share. Moreover, even in countries with increased economy-wide female employment share (excluding France), sectoral shifts in employment have led to a decline in the female employment share. These findings imply that in these countries the production structure in the economy changed so as to increase the share of sectors with low female employment share, consistent with the findings of Table 2. Withinsector changes (Term II) also denote a negative effect in the seven countries with the highest decrease in female employment share (Greece, Finland, Sweden, Republic of Korea, UK, US and Japan). In other words, while the production and employment have shifted to sectors where female employment share is low, use of female labor in each sector has also decreased in these seven countries. In the other OECD-HI countries, within sector changes have worked towards an increase in the demand for female labor. But in some of these countries (Portugal, Italy and Germany) as the effect of between sector changes (Term I) is higher than the within sector changes (Term II), the result is lower relative demand for female labor.

The female employment share in all OECD-MI countries decreased with both the between sector changes (except Turkey) and the within sector changes (except Hungary) bringing female labor demand to lower levels. The data of the other developing countries display a more mixed picture. The share of female employment in total employment increased in six of the ten countries, decreasing in the other ones. However, the between-sector shifts mostly increased the female share of labor (except Kazakhstan and Lithuania) while withinsector changes mostly decreased the female share (except Indonesia, Lithuania, Philippines and Jordan). If we assume that international trade causes a shift of labor between sectors, the analysis above implies that trade has led to decreased demand for female labor in OECD-HI and OECD-MI countries, while increasing it in other developing countries. Thus based on the ongoing observations, we can conclude that contrary to OECD countries, other developing countries export female labor intensive products. ${ }^{10}$

\footnotetext{
${ }^{10}$ If we further decompose the contribution of different sectors to the between sector shifts of female employment (Term I) we observe that the highest contribution to this decrease comes from industries 17 (Manufacture of textiles), 18 (Manufacture of wearing apparel; dressing and dyeing of fur) and 19 (Tanning and dressing of leather; manufacture of luggage, handbags, saddlery, harness and footwear). These are the relatively low technology sectors with highest share of female labor. In general, in the OECD-HI countries, during 1990s and 2000s the structure of
} 


\section{FACTOR CONTENT ANALYSIS}

In order to measure the changes in total and female employment due to changes in the structure of international trade at the country and sector level, we employ factor content analysis. The analysis incorporates ISIC Rev.3 2-digit manufacturing sub-sectors. Using the factor content analysis, we are able to establish, in absolute terms, how total and female employment change with changing export and import patterns between the 1990s and the 2000s. As in Kucera and Milberg (2000; 2003), we first calculate the change in international trade structure in each country and each manufacturing sector from the 1990s into the 2000s as follows:

$$
T=X^{2000 s}-M^{2000 s}-x^{1990 s} D^{2000 s}-m^{1990 s} D^{2000 s}
$$

where $T$ is the vector of changes in international trade structure ${ }^{11}, X$ and $M$ are the vectors of export and import values, and $x$ and $m$ represent the export and import propensities (share of total

exports and imports in final demand, $D$ ), respectively. Alternatively, $T$ can be written as

$$
T=X^{2000 s}-M^{2000 s}-X^{1990 s}-M^{1990 s} \frac{D^{2000 s}}{D^{1990 s}}
$$

where $D$ represents the vector of final demand, i.e.

$$
D=I-A Q+M
$$

Here, $A$ is the technical coefficients matrix from input-output tables for each country, $I$ is the identity matrix, $Q$ is the vector of domestic output and $M$ is the vector of imports. $T$ also represents the effect of changes in trade on final demand (under the assumption that domestic demand remains constant between periods).

In the next step of the factor content analysis, we measure how this change in final demand originating from changes in structure of trade affects employment. Below, $L$ gives an account of how total manufacturing employment is affected by a change in the structure of trade:

$$
L=E(I-A)^{-1} T
$$

Above, $L$ is the vector of changes in manufacturing employment due to changes in the structure

production changed in a way to move employment away from the sectors with high female share.

A similar pattern is seen in the OECD-MI countries although to a lesser extent. The picture is less clear in the other developing countries. Negative contributions are observed from sectors with all levels of female share.

${ }^{11} T$ is the difference between actual net exports at the end of the period and the hypothetical net exports had the trade propensities remained the same throughout the period. 
of trade in manufactures, and $\hat{E}$ is the diagonal matrix of labor coefficients (employment per unit of output). From here, we can also calculate the change in female employment associated with a change in the structure of trade as:

$$
L^{f}=G L
$$

Where $\hat{G}$ is the diagonal matrix of female coefficients of employment (share of female employees in total employment).

\section{Country-level Analysis}

Examining Tables 6 and 7 together, we observe that out of 16 OECD-HI countries, nine were negatively affected by changes in trade patterns in terms of total employment, and ten in terms of female employment. In the North, had the trade structure stayed the same over the period, total and female employment in manufacturing would have been about 2 million and about 803 thousand workers higher than the actual, respectively. This indicates that total employment in manufacturing in the North would have been 3.5 percent higher if the trade structure stayed the same throughout the period. Almost all of this negative employment effect in OECD-HI countries is due to trade expansion with the OECD-MI and ODCs, including China. The changes in the structure of trade have caused an even higher estimated drop in female employment at 4.3 percent in this group over the period. For the ten OECD-HI countries for the 1978-95 period, Kucera and Milberg (2003) find that the estimated decline in total employment due to the change in the structure of trade is at 5.3 percent, and almost all of this decline is due to the trade expansion with the South during the period, thus we can deduce that the negative employment effect of expansion of trade with the South has continued into the early 2000s. 
Table 6. Country-level total manufacturing employment effects from change in trade structure

\begin{tabular}{|c|c|c|c|c|c|c|c|}
\hline & $\begin{array}{r}\text { Absolute } \\
\text { effects } \\
\text { from trade } \\
\text { (thousand } \\
\text { people) }\end{array}$ & $\begin{array}{r}\text { Change } \\
\text { Relative } \\
\text { to } 1990 \mathrm{~s} \\
\text { mfg. } \\
\text { emply. } \\
(\%)\end{array}$ & $\begin{array}{r}\text { Realized } \\
\text { change } \\
\text { from } \\
1990 \mathrm{~s} \text { to } \\
2000 \mathrm{~s} \\
(\%)\end{array}$ & & $\begin{array}{r}\text { Absolute } \\
\text { effects } \\
\text { from trade } \\
\text { (thousand } \\
\text { people) }\end{array}$ & $\begin{array}{r}\text { Change } \\
\text { Relative } \\
\text { to } 1990 \mathrm{~s} \\
\text { mfg. } \\
\text { emply. } \\
(\%)\end{array}$ & $\begin{array}{r}\text { Realized } \\
\text { change } \\
\text { from } \\
1990 \mathrm{~s} \text { to } \\
2000 \mathrm{~s} \\
(\%)\end{array}$ \\
\hline OECD HI & & & & OECD MI & & & \\
\hline Austria & 102.0 & 13.3 & -5.7 & Czech Rep. & 212.1 & 15.8 & -2.7 \\
\hline Denmark & -15.2 & -3 & -10.9 & Hungary & 99.4 & 11.2 & 2.8 \\
\hline Finland & -4.1 & -1 & 5.4 & Slovak Rep. & 784.6 & 256 & 17.2 \\
\hline France & -188.3 & -4.5 & -0.1 & Slovenia & 6.2 & 2.2 & -4.6 \\
\hline Germany & 359.4 & 4.2 & -3.1 & Turkey & 59.1 & 5.5 & 66.9 \\
\hline Greece & 6.6 & 1.2 & -0.6 & Total & $1,161.4$ & 29.7 & 19.3 \\
\hline Ireland & -12.8 & -4.9 & 7.9 & $O D C s$ & & & \\
\hline Italy & -396.0 & -8.1 & 0.1 & Bulgaria & -932.8 & -134.9 & -13.7 \\
\hline Japan & 4.8 & 0 & -13.4 & India & -250.3 & -3.2 & 0.1 \\
\hline Netherlands & 78.7 & 7.3 & -2.6 & Indonesia & 567.8 & 13.6 & 5.2 \\
\hline Portugal & 23.8 & 2.3 & -1.7 & Jordan & 53.6 & 62.3 & 49.7 \\
\hline Rep.of Korea & 195.6 & 7.5 & -0.6 & Kazakhstan & -89.4 & -18.5 & -14.4 \\
\hline Spain & -284.9 & -11.1 & 18.7 & Latvia & 155.4 & 72.2 & 19.6 \\
\hline Sweden & -4.6 & -0.6 & -6.4 & Phillipines & 63.1 & 5.7 & -10.7 \\
\hline UK & -273.9 & -5.5 & -15.4 & Romania & -416.7 & -18.1 & -12.9 \\
\hline US & $-1,735.2$ & -9.3 & -9.1 & Thailand & 288.6 & 13.1 & 43.9 \\
\hline Total & $-2,145.0$ & -3.5 & -6 & Total & -560.7 & -2.9 & 3.6 \\
\hline
\end{tabular}


Table 7. Country-level female manufacturing employment effects from change in trade structure

\begin{tabular}{|c|c|c|c|c|c|c|c|}
\hline & $\begin{array}{r}\text { Absolute } \\
\text { effects } \\
\text { from trade } \\
\text { (thousand } \\
\text { people) }\end{array}$ & $\begin{array}{r}\text { Change } \\
\text { Relative } \\
\text { to } 1990 \mathrm{~s} \\
\text { female } \\
\text { mfg. } \\
\text { emply. } \\
(\%)\end{array}$ & $\begin{array}{r}\text { Realized } \\
\text { change } \\
\text { from } \\
1990 \text { s to } \\
2000 \mathrm{~s} \\
(\%)\end{array}$ & & $\begin{array}{r}\text { Absolute } \\
\text { effects } \\
\text { from trade } \\
\text { (thousand } \\
\text { people) }\end{array}$ & $\begin{array}{r}\text { Change } \\
\text { Relative } \\
\text { to } 1990 \mathrm{~s} \\
\text { female } \\
\text { mfg. } \\
\text { emply } \\
(\%)\end{array}$ & $\begin{array}{r}\text { Realized } \\
\text { change } \\
\text { from } \\
1990 \mathrm{~s} \text { to } \\
2000 \mathrm{~s} \\
(\%)\end{array}$ \\
\hline OECD HI & & & & $O E C D M I$ & & & \\
\hline Austria & 25.5 & 12.4 & -10.8 & Czech Rep. & 104.6 & 19.5 & -6.9 \\
\hline Denmark & 0.7 & 0.5 & -16 & Hungary & 30.5 & 8.5 & 1.9 \\
\hline Finland & -10.9 & -8.9 & 4.5 & Slovak Rep. & 474.3 & 277.3 & -17.3 \\
\hline France & -55.0 & -4.4 & -1.8 & Slovenia & -2.1 & -1.8 & -10.5 \\
\hline Germany & 94.6 & 3.9 & -3.6 & Turkey & -34.0 & -14.2 & \\
\hline Greece & -11.5 & -6.9 & -10.2 & Total & 573.2 & 40.4 & -6.1 \\
\hline Ireland & -3.9 & -5.4 & 4.9 & $O D C s$ & & & \\
\hline Italy & -97.4 & -6.7 & -0.1 & Bulgaria & -412.8 & -119.7 & -9.7 \\
\hline Japan & -68.8 & -2 & -16.4 & India & -16.6 & -1.8 & -4.2 \\
\hline Netherlands & 8.3 & 4 & 1.4 & Indonesia & 270.1 & 13.7 & 5.1 \\
\hline Portugal & -2.4 & -0.6 & -0.1 & Jordan & 16.3 & 193.9 & 109.4 \\
\hline Rep.of Korea & 37.6 & 4.6 & -3.4 & Kazakhstan & -13.0 & -7.1 & -23.3 \\
\hline Spain & -65.5 & -11.4 & 31.6 & Latvia & 71.0 & 62.2 & 5.9 \\
\hline Sweden & 3.1 & 2 & 10.9 & Phillipines & 33.1 & 6.5 & -3.3 \\
\hline UK & -78.6 & -5.9 & -20.7 & Romania & -116.3 & -11.5 & -6.8 \\
\hline US & -579.0 & -9.7 & -12.6 & Thailand & 90.3 & 7.3 & 38.8 \\
\hline Total & -803.2 & -4.3 & -8.4 & Total & -77.8 & 6.2 & -1.2 \\
\hline
\end{tabular}

Among the OECD-HI countries, the US has by far the largest estimated employment losses from the change in structure of trade: 81 percent of the employment losses in the North originate in the US. The majority of the estimated job losses in manufacturing in the US are due to the expansion of trade with China at 42 percent of the total. Kucera and Milberg (ibid.) has shown that for the period 1978-95, the US has had the largest estimated job losses in manufacturing among all North countries, again the bulk of the losses originating from trade with non-OECD countries. We confirm that this trend in the US has continued from the 1990s into the early 2000s, and we can specify the main source of job losses in manufacturing as Chinese trade. This result is consistent with the changing pattern of trade between the US and China in manufactures in the 2000s with China's accession to the WTO in 2001; from the late 1990s into early 2000s, the US has consistently run a trade deficit with China. The estimated fall in female employment in US manufacturing is even more prominent at 9.7 percent, and 46 
percent of this estimated fall in female employment can be attributed to the change in the structure of trade with China. With this outcome we can conclude that female manufacturing jobs have been hit harder with Chinese trade in the US than overall employment in the early 2000s.

For the 1978-95 period in Kucera and Milberg's analysis, Japan appeared to be the second largest loser in terms of manufacturing employment due to the expansion of trade, particularly with the developing world. ${ }^{12}$ However in our study for the late 1990 s to early 2000 s, Japan is not among the countries which are negatively affected in terms of manufacturing employment; Japan's job gains from trade with the rest of the North have slightly surpassed the job losses experienced from trade with China and the rest of the South. Kucera and Milberg (2000) reported that Japan had gains in employment for the period from 1970-91, from world and OECD trade, with some losses from non-OECD trade. We can say that after the 1980s into the early 1990s, when Japan experienced employment losses in manufacture, she has started to recover in early the 2000s. Although there is no discernible negative effect in overall employment, there is clearly a negative effect on female employment in Japanese manufacturing in the period that we consider. Moreover, this negative effect is mainly due to trade with China and some with the rest of the South, as trade with the North has a positive effect on Japanese female manufacturing employment. Nevertheless, the estimated losses from the South and China far exceed the gains from the North.

Among the North countries, the biggest relative gainers in total employment appear to be Austria, Republic of Korea, Netherlands and Germany. Except for Republic of Korea, these countries all have large gains in employment from North trade in manufactures; Republic of Korea's gain is chiefly due to trade with China and the South, unlike other countries. Although at slower rates, these countries also have estimated gains in female manufacturing jobs between the late 1990s and early 2000s. Interestingly, Republic of Korea is the only country that has estimated gains in female employment from trade with China in this period.

\footnotetext{
12 In the North, after the US Italy is the second largest loser in manufacturing jobs due to changes in the structure of trade between the late 1990s and early 2000s. According to Kucera and Milberg's analysis for 1978-1994, although Italy appeared to be negatively affected from overall world trade, the losses remained at only 1.1 percent and Italy in fact gained from trade with the OECD countries. However for the period that we examine, Italy is estimated to have lost about 400 thousand jobs from overall world trade (including China, North and the South), which is a loss of 8 percent of manufacturing employment. In Italy, the job losses due to change in structure of trade with the North surpass the job losses from trade with the rest of the world.
} 
Generally, in the countries where both total and female employment are negatively affected, the rate at which female employment decreases exceeds the rate at which total employment decreases, and reversely in countries where both the total and female employment record increases due to changes in trade patterns, female employment has increased at a slower rate than total employment. Both of these observations point to a negative gender bias against female employment, as shown in Table 8: out of 16 North countries, 12 have experienced negative gender bias against female employment as a result of changes in trade patterns from late 1990s to early 2000s. These results agree with the within-sector shifts found previously in the decomposition analysis. With respect to trading partners, we observe that except for Republic of Korea, all other North countries are negatively affected by trade with China in terms of both total and female employment demand (Tables A3 and A4 in Appendix), and in countries where overall female employment is negatively affected, the impact from Chinese trade appears to be stronger.

In actual terms, total manufacturing employment in the North has declined by 6 percent (by 3.7 million) from the late 1990s into the early 2000s, and about 60 percent of this change can be attributed to the estimated effect of trade expansion. Out of this estimated effect, 60 percent is accounted for by Chinese (by 1.3 million), 35 percent by South and only 5 percent by North manufacturing trade expansion. This implies that Chinese trade expansion with the North in the early 2000s accounts for about 34 percent of deindustrialization. We also observe a definite decline in share of industry employment in total employment in all North countries, though at varying degrees. This indicates that the deindustrialization process reported by Kucera and Milberg (2003) in 10 OECD countries during the 1978-1995 period has continued into the 2000s. 
Table 8. Gender bias measure (\% change in female employment minus $\%$ change in male employment)

\begin{tabular}{rrrr}
\hline & $\begin{array}{c}\text { Female\%- } \\
\text { Male\% }\end{array}$ & \multicolumn{2}{c}{$\begin{array}{c}\text { Female\%- } \\
\text { Male\% }\end{array}$} \\
\hline OECD HI & \multicolumn{3}{c}{ OECD MI } \\
Austria & -1.67 & Czech Rep. & 6.20 \\
Denmark & 5.25 & Hungary & -4.91 \\
Finland & -11.21 & Slovak Rep. & 48.19 \\
France & 0.13 & Slovenia & -6.77 \\
Germany & -0.40 & Turkey & -25.21 \\
Greece & -12.37 & ODCs & \\
${ } }$ & -0.09 & Bulgaria & 30.25 \\
Italy & 2.05 & India & 1.59 \\
Japan & -3.15 & Indonesia & 0.04 \\
Netherlands & -5.75 & Jordan & 145.82 \\
Portugal & -5.14 & Kazakhstan & 18.25 \\
Rep.of Korea & -4.27 & Lithuania & -21.25 \\
Spain & -0.34 & Phillipines & 1.47 \\
Sweden & 3.51 & Romania & 11.66 \\
UK & -0.42 & Thailand & -13.11 \\
US & -0.62 & & \\
\hline
\end{tabular}

On the other hand, out of 14 South (OECD-MI and ODCs) countries, only four were negatively affected from changes in trade patterns in terms of total employment, but six were negatively impacted in terms of female employment demand. In the countries where total employment has decreased, female employment has also decreased, but at a slower rate than total employment. Therefore in these countries we observe a positive gender bias in favor of female employment. Interestingly, in Slovenia and in Turkey, although there is a positive impact on total employment, female employment has been negatively affected, indicating that in these countries, female labor intensive industries have been particularly disadvantaged in response to trade expansion especially from China and the rest of the South. Out of the remaining eight countries where both total and female employment are positively impacted from changes in structure of foreign trade, in Czech Republic, Indonesia, Jordan and Philippines, we observe a positive gender bias favoring female employment, implying that the rise in female employment has exceeded the rise in male employment in response to trade changes, while in Hungary, Lithuania, Slovenia and Thailand, a negative gender bias against female employment occurs due 
to the fact that female employment has risen at a slower rate than male employment. Nevertheless, in the South we deduce that the positive impact of changes in the structure of trade on female employment dominates the positive impact on total employment; in fact, the estimated gains in female employment account for 82 percent of the estimated gains in total employment in the South. In terms of trading partners, all South countries except for Philippines have been negatively impacted by Chinese trade in terms of both total and female employment demand. That is, even though a country has experienced a positive impact on employment from overall changing trade patterns, the impact from China is consistently negative.

\section{Industry-level Analysis}

For the North as a whole, in all manufacturing sectors except motor vehicles (34) and to some extent petroleum products (23), we estimate losses all around in total employment due to changes in trade structure from the late 1990s to early 2000s. For 34, the estimated employment losses experienced in other countries are compensated by large increases in Germany, Republic of Korea and Japan. However, these increases are mainly due to trade with other North countries (there is some slight negative effect from trade with the South). Kucera and Milberg (2003) estimated employment losses in the North in all industries except in aircraft (35) and petroleum and coal products (23) industries between 1978 and 1995. We see that 34 has recovered at least in Germany and Japan as compared to Kucera and Milberg's analysis; Republic of Korea was not included in Kucera and Milberg's group of ten rich countries. Otherwise the estimated employment losses in all other industries persist into the 2000s.

The South, on the other hand, is estimated to experience a positive impact on overall employment, with mixed outcomes in individual industries. However in particular 34, 30+32, $29+31+33$, and finally in 17 , the South experiences employment gains from trade expansion. In 34, the large gains are experienced particularly in Slovak Republic, in 30+32 in Czech Republic and Slovak Republic, in 29+31+33 in Czech Republic, Indonesia and Thailand. In 17, largely Indonesia, and then India stand out as the large gainers in total employment. These support the topped growth of output of manufacturing of machinery and motor vehicles in East European countries over the period and indicate a major transition in the production of traditional sectors including textiles mainly to Asia.

Tables 9 and 10 show industry-level female employment effects from changes in trade structure for North and South. The manufacturing sub-sectors in these tables are ranked from 
least to most female-labor intensive, and the countries are arranged from most affected to least affected. Accordingly, textiles, wearing apparel and leather industries (17 and 18) are the most female-labor intensive, while manufacture of motor vehicles, trailers and semi-trailers and other transport equipment (34 and 35), basic metals, coke, refined petroleum and nuclear fuels (23 and 27) are the least female-labor intensive. In terms of sectoral impacts, we observe that in almost all North countries, in labor intensive sectors such as 17 and 18, female employment has been negatively affected from the changes in trade structure. Although the female employment share is not as high as in the labor intensive sectors, in $30+32$, out of 16 North countries, ten have seen significant decreases in female employment, which can be justified by the shift to the South in the production of these goods (particularly, in the OECD-MI countries of the South, such as Slovenia, Turkey, Hungary and Czech Republic, we see significant increases in female employment with respect to this sector). On the other hand, in the North, the majority of the countries (Ireland, Netherlands and Republic of Korea leading) experience increases in female employment in the manufacture of $29+31+33$. The increase in female employment in these sectors is significant in the sense that the share of female employment reaches 22 to 23 percent of total employment in the respective countries. Other notable estimated positive effects from trade on female employment are in the manufacture of chemicals and plastics $(24+25)$ especially in Sweden, Republic of Korea and Austria, and in 34 in Republic of Korea, Germany, Austria, and somewhat in Japan. In the North, while some countries experience negative effects on female employment across almost all manufacturing sectors (such as Spain, US, Italy, UK and France), in some other countries important gains in female jobs can be estimated in less femaleintensive sub-sectors, as in Japan, Germany, Netherlands, Republic of Korea and Austria. Especially in the Netherlands and Republic of Korea, while estimated losses in 17 and 18 are large, these losses are outweighed by gains in female jobs in less female intensive (or higher value-added) industries, leading to a positive estimated effect of changes in trade patterns in these countries. Results from Germany, the Netherlands, Republic of Korea and Austria point out that compared to the 1990s, demand for female employment has shifted towards traditionally male-dominated industries in the early 2000s due to expansion of trade in these industries.

With our analysis, we observe that the large employment losses in the North in 17 and 18 in the 1978-1995 period (as in Kucera and Milberg, 2003) has continued into the early 2000s. But the important issue to point out is that in the majority of the North countries (10 of them for 
which we have female employment data), gender bias in these sectors is positive, meaning that the fall in female employment was at a slower rate than male employment, which implies that female jobs continued to dominate in these sectors. Interestingly, Italy, which was considered to have competitive success in the industry, has also experienced total and female employment losses, unlike in the period analyzed in Kucera and Milberg.

In the South countries, we do not observe a clear-cut pattern in terms of the impact of foreign trade in sub-sectors in manufacturing. For example, in OECD-MI countries, while we see almost a uniform negative impact on female employment in labor intensive sectors of 17 and 18, the impact is mixed in the remaining developing countries, for example, countries as Philippines, Indonesia and Jordan show important increases in female employment in the textile industry. The one sector that we observe significant increases in female employment almost uniformly in the South is 34. In terms of increases in female employment this sector is significant in the sense that share of female employment exceeds 20 percent on average in these countries. Although the female labor share is relatively low, as mentioned in the above paragraph, there are important positive changes in female employment in $29+31+33$ in the South, which is parallel to the development in total employment in these countries. 
Table 9. Country and manufacturing sub-sector level female manufacturing employment effects from change in trade structure (OECD-HI, \% changes from 1990s female employment)

\begin{tabular}{|c|c|c|c|c|c|c|c|c|c|c|c|c|c|c|c|c|}
\hline $\begin{array}{c}\mathbb{Z} \\
0 \\
0 \\
0 \\
0\end{array}$ & $\begin{array}{l}\Xi \\
\text { ڤ్ } \\
\text { क }\end{array}$ & $\tilde{D}$ & 吾 & 尚 & 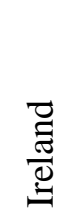 & 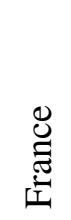 & 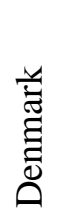 & $\underset{\text { 诘 }}{\stackrel{\vec{\Xi}}{\Xi}}$ & 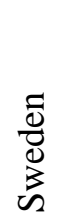 & 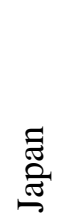 & $\begin{array}{l}8 \\
\mathbb{d} \\
\stackrel{0}{0}\end{array}$ & 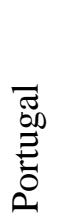 & 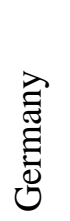 & 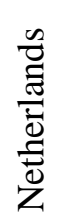 & 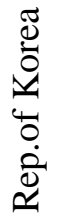 & 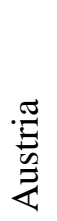 \\
\hline 23 & & -1 & & -2 & & -4 & & & & 7 & & & & & 22 & \\
\hline 35 & -14 & 0 & -10 & 2 & & 1 & & & & 3 & & & -7 & & 7 & \\
\hline 27 & -21 & -23 & -36 & -8 & & -11 & & & & 12 & & & 4 & & -25 & 4 \\
\hline 34 & -32 & -8 & -21 & -5 & & -5 & & & -6 & 9 & & 2 & 14 & & 16 & 48 \\
\hline 20 & -16 & -7 & -2 & -3 & & -5 & & -5 & & -2 & & 1 & 11 & & -5 & 19 \\
\hline 28 & -20 & -12 & -8 & -6 & -3 & -7 & -9 & -5 & -9 & 0 & & 3 & 0 & 5 & 13 & 7 \\
\hline 26 & -7 & -5 & -11 & -5 & -34 & -6 & -7 & & & 1 & -10 & 2 & 8 & & 2 & 15 \\
\hline $29+31+33$ & -14 & -5 & -4 & -6 & 30 & -5 & 3 & 1 & 3 & 2 & 20 & 0 & 6 & 23 & 27 & 16 \\
\hline $36+37$ & -15 & -4 & -11 & -14 & -34 & -5 & -5 & -6 & & -1 & 5 & 5 & 3 & 2 & -6 & 9 \\
\hline $24+25$ & -7 & -12 & -6 & -4 & 7 & -2 & 4 & -1 & 19 & -2 & -9 & 4 & 2 & 9 & 16 & 25 \\
\hline $21+22$ & 0 & -7 & -3 & -1 & -36 & -1 & 3 & -8 & 4 & -1 & 26 & -2 & 6 & 7 & 2 & 0 \\
\hline $30+32$ & -68 & -37 & -32 & -14 & -13 & -19 & -12 & -44 & 2 & 0 & & 39 & -3 & 5 & 15 & 30 \\
\hline $15+16$ & -1 & -2 & 2 & -6 & -2 & 1 & -3 & -4 & 0 & -1 & -1 & 3 & 1 & 2 & 5 & 24 \\
\hline 19 & -13 & -36 & -7 & -27 & & 3 & & & & -15 & -10 & -3 & 10 & & -17 & 4 \\
\hline 17 & -20 & -21 & -4 & -13 & -112 & -13 & 12 & -9 & & -10 & -23 & 5 & 2 & -3 & -11 & -6 \\
\hline 18 & -12 & -15 & -6 & & & -9 & 18 & -21 & & -20 & -18 & -7 & 4 & -43 & -13 & \\
\hline Total & -11 & -10 & -7 & -6 & -5 & -4 & 0 & -9 & 2 & -2 & -7 & -1 & 4 & 4 & 5 & 12 \\
\hline
\end{tabular}


Table 10. Country and manufacturing sub-sector level female manufacturing employment effects from change in trade structure (OECD-MI and ODCs, \% changes from 1990s female employment)

\begin{tabular}{|c|c|c|c|c|c|c|c|c|c|c|c|c|c|c|c|}
\hline 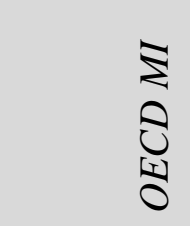 & 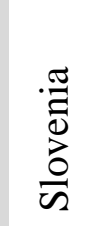 & $\begin{array}{l}\stackrel{\vec{d}}{\leftrightarrows} \\
\stackrel{\Xi}{\Xi}\end{array}$ & $\begin{array}{l}\text { 悹 } \\
\text { 品 } \\
\text { 言 }\end{array}$ & 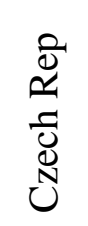 & 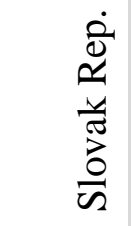 & $\frac{0}{0}$ & 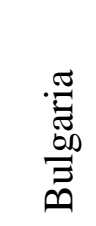 & 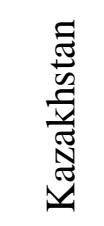 & 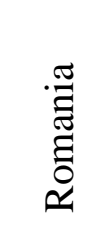 & 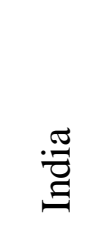 & 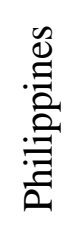 & 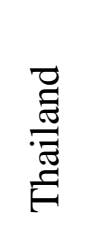 & 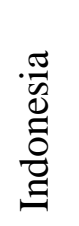 & 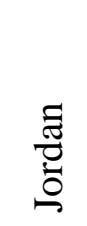 & 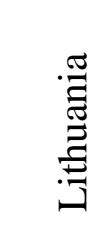 \\
\hline 23 & & -29 & & & & & & -26 & -19 & -37 & 0 & 124 & 30 & 11 & -15 \\
\hline 27 & 0 & 10 & -80 & -13 & 55 & & -250 & -45 & -53 & 4 & -22 & 98 & 3 & 208 & 560 \\
\hline 35 & & 258 & & -16 & -916 & & -178 & 339 & & -36 & 58 & 218 & -7 & & 75 \\
\hline 28 & -3 & 79 & -16 & -53 & 43 & & -187 & -73 & -22 & 1 & -10 & 15 & 32 & 34 & 661 \\
\hline 20 & 0 & 111 & & 1 & 27 & & -371 & 85 & -19 & -43 & 37 & 42 & 5 & 129 & -87 \\
\hline 34 & 32 & 50 & 81 & & 11,901 & & -503 & -276 & -195 & 8 & 86 & 26 & 40 & 2 & 2,158 \\
\hline 26 & -8 & 6 & -1 & -4 & & & -500 & 19 & -31 & 0 & 6 & 11 & & -8 & -23 \\
\hline $36+37$ & 17 & 65 & 4 & 9 & 3 & & -58 & -42 & -17 & -125 & 1 & -4 & -34 & 39 & 275 \\
\hline $29+31+33$ & 16 & 43 & 19 & 44 & & & -102 & -123 & 7 & -4 & 40 & 95 & 59 & 75 & 115 \\
\hline $24+25$ & 38 & -17 & 17 & 1 & 0 & & -178 & -69 & -50 & 1 & -7 & 26 & 21 & 12 & 91 \\
\hline $21+22$ & 3 & 11 & -3 & 11 & 20 & & -97 & 787 & -1 & -6 & -13 & 8 & -9 & 23 & 125 \\
\hline $15+16$ & -13 & 1 & 29 & -13 & -72 & & -64 & -5 & -7 & 2 & -3 & 2 & 9 & 1 & 28 \\
\hline $30+32$ & -22 & 87 & 64 & 699 & 2,666 & & 19 & -97 & 63 & -52 & -44 & -30 & 20 & & 49 \\
\hline 17 & -24 & -24 & -7 & -7 & & & -284 & -38 & -20 & 3 & 44 & -8 & 60 & 139 & 2 \\
\hline 19 & -28 & -36 & -43 & -59 & & & -85 & 225 & 13 & -6 & -7 & -23 & 3 & 19 & -115 \\
\hline 18 & -18 & -51 & & -19 & & & 4 & -54 & 11 & 6 & 32 & -15 & -7 & 634 & 20 \\
\hline Total & -2 & -14 & 9 & 20 & 277 & & -120 & -7 & -12 & -2 & 7 & 7 & 14 & 194 & 62 \\
\hline
\end{tabular}

\section{CONCLUSION}

In this paper we use structural decomposition and factor-content based analysis to explore the employment effects of trade in manufacturing industry over the period 1995-2006. We provide estimates for total and women's employment effects of world trade evaluating the changes in trade flows in 30 countries ( 21 OECD and 9 non-OECD countries) for 23 manufacturing sectors by breaking up the sources of these changes between the trade with the North, the South and China. The structural decomposition of the changes in female share of employment by sector into two components as between- and within-sector changes enabled us to measure the contribution of each component, where the former reflects the impacts of the changes in production due to trade. The factor-content analysis provides estimates for total and women's 
employment effects of trade by taking the difference between actual size of employment, and the hypothetical size that would have been assuming trade propensities stayed the same over the period of analysis.

Our results present a net negative impact of trade on total employment as well as on women's employment in 30 countries over the period of analysis. In the North, we've found that total employment (by 2 million) and women's employment (by 803 thousand) in manufacturing would have been around 4 percent higher had the trade structure remained the same throughout the period. Country level results show that the United States has by far the largest estimated employment losses from the change in structure of trade: 81 percent of the employment losses in the North originate in the US and the majority of the estimated job losses are due to the expansion of trade with China at 42 percent of the total. In almost all countries in the North, excluding a few gainers (Austria, Republic of Korea, Netherlands and Germany), both total and female employment are negatively affected, where the rate at which decline in female employment exceeds that of total employment. On the other hand, in countries where both the total and female employment record increases due to changes in trade patterns, female employment has increased at a slower rate than total employment, both of which indicate a gender bias in employment effects of trade.

The structural decomposition analysis provided supporting evidence for gender bias in the North by revealing that the decline in the female share of employment occurred more due to the shift of the production between sectors potentially induced by trade. The production structure in manufacturing changed so as to increase the share of sectors with low female employment share, and in some of the countries including the US, while the production and employment have shifted to sectors where female employment share is low, use of female labor in each sector has also decreased.

On the other hand, in the South, out of 14 countries, only four were negatively affected from changes in trade patterns in terms of total employment, but six were negatively impacted in terms of female employment. Overall positive employment changes due to trade were obtained despite the negative effects of trade with China. In the countries where total employment has decreased, female employment has also decreased, but at a slower rate than total employment. Therefore in these countries we observe a positive gender bias in favor of female employment. Interestingly, in Slovenia and in Turkey, although there is a positive impact on total employment, female employment has been negatively affected, indicating that in these 
countries, female labor-intensive industries have been particularly disadvantaged in response to trade expansion, especially from China and the rest of the South.

These country-level results clearly indicate that the so-called 'deindustrialization' process that had started in the North in the 1980s towards the 1990s has also continued in the early 2000s, implying that the shift of the manufacturing activities from the North to the South persisted particularly for the traditional low technology manufacturing sectors. We observe that in the early 2000s China dominates this shift in manufacturing trade, as almost all countries both in North and South have a negative impact in their manufacturing sector due to trade with China. The sector-level results present this more clearly. We observe significant declines in female share of employment in the traditional and female labor-dominated subsectors in all countries. Relatively more female labor-intensive sectors have been more disadvantaged - a result consistent with earlier findings. However, we observe this not only in the North but also in the South (except in Philippines). Different than previous studies, we find that in the North the demand for female employment has partly shifted towards traditionally male-dominated industries in the early 2000s, in the industries where the production and export shares of the South show major rises over the period, such as the manufacture of motor vehicles, machinery, office equipment, TV and communication equipment. We also see positive changes in female employment in these subsectors in the South. These are mainly the sectors where internationalization of production is more widespread and perhaps the competition is more severe at the global scale. 


\section{REFERENCES}

Albelda, R.; Drago, R.; Schulman, S. 2004. Unlevel Playing Fields: Understanding Wage Inequality and Discrimination (Economic Affairs Bureau, second edition).

Athukorala, P. 2009. "The Rise of China and East Asian Export Performance: Is the CrowdingOut Fear Warranted?", The World Economy 32 (2), 234-266.

Attanasio, O., Goldberg, P.K and N. Pavcnik .2004. "Trade Reforms and Wage Inequality in Colombia”, Journal of Development Economics 74 (2), 331-366.

Becker, G.S. 1971. The Economics of Discrimination (University of Chicago Press, second edition).

Berik, G. 2011. "Gender Aspects of Trade" in Jansen, M., Peters, R. and J.M. Salazar-Xirinachs (eds.) Trade and Employment From Myths to Facts, 61-125, ILO: Geneva.

Berik, G. 2000. "Mature export-led growth and gender wage inequality in Taiwan", Feminist Economics 6 (3), 1-26.

Berik, G., Van Der Meulen Rodgers, Y. and Zvecglich J. E. 2004. 'International Trade and Gender Wage Discrimination: Evidence from East Asia'. Review of Development Economics 8, 237-254.

Black, S.E.; Brainerd, E. 2004. "Importing equality? The impact of globalization on gender discrimination", Industrial and Labor Relations Review 57 (4), 540-559.

Çağatay, N. (1996). "Gender, trade and the World Trade Organization," in ESCAP Asian and Pacific, Developing economies and the first WTO Ministerial Conference: Issues of concern. New York, United Nations.

Çagatay, N. and Özler, S. 1995. "Feminisation of the labor force: the effects of long-term development and structural adjustment", World Development 23 (11), 1883--94.

Cagatay, N., 2001. "Trade, Gender and Poverty", Background Paper for the Trade and Sustainable Human Development Project, New York: UNDP.

Cagatay, N., D. Elson, and C. Grown, 1995. "Introduction", World Development 23 (11), 182736. 2000. "Introduction”,World Development 28 (7), 1145-56.

Carr, M.; Chen, M.A.; Tate, J. 2000. "Globalization and Home-based Workers", Feminist Economics, 6 (3), 123-142.

Elson, D. 1996. "Appraising Recent Developments in The World Markets for Nimble Fingers". in, Chachhi, A., and R. Pittin (eds.), Confronting the State, Capital and Patriarchy: Women Organizing in The Process of Industrialization. Basingstoke: Macmillan. 
Elson, D. and Pearson, R. 1981. "Nimble Fingers Make Cheap Workers: An Analysis of Women's Employment in Third World Export Manufacturing". Feminist Review 7 (Spring), 87-107

Elson, D. 1999. "Labor Markets As Gendered Institutions: Equality, Efficiency and Empowerment Issues”, World Development 27 (3), 611-627.

Ghosh, J. 1996. "Gender, trade and the WTO: issues and evidence from developing Asia”, Paper for UN Economic and Social Commission for Asia and the Pacific, in preparation of First WTO Ministerial Conference, 4--6 September 1996, Jakarta.

Gibson, B. 2011. "Assessing the Impact of Trade on Employment" in Jansen, M., Peters, R. and J.M. Salazar-Xirinachs (eds) Trade and Employment From Myths to Facts, 61-125, ILO: Geneva.

Goldberg, P.K. and N. Pavcnik. 2003. "The Response Of The Informal Sector To Trade Liberalization”. Journal of Development Economics 72, 463-496.

Goldberg, P.K. and N. Pavcnik. 2004. Trade, inequality, and poverty: What do we know? Evidence from recent trade liberalization episodes in developing countries. Brookings Trade Forum, Globalization, Poverty, and Inequality, 223-269.

Greenaway, D., A. Mahabir, C. Milner .2008. "Has China Displaced Other Asian Countries' exports?" China Economic Review 19, 152-169.

Holst, D. R., J. Weiss .2004. "ASEAN and China: Export Rivals or Partners in Regional Growth?" The World Economy 27 (8), 1255-1274.

Isaza-Castro, Jairo G. 2012. Female Intensity, Trade Reforms and Capital Investments in Colombian Manufacturing Industries: 1981-2000, PhD. Thesis, University of Sussex, UK.

Joekes, S. and Weston, A. 1994. Women and the New Trade Agenda, UNIFEM, New York.

Krueger, A., H. B. Lary, T. Momon, N. Akrasanee (eds.), (1981) Trade and employment in developing countries, Vol. 1: Individual Studies. Chicago.

Kucera, D. and W. Milberg, 2003. 'Trade expansion and employment in OECD: New factor content calculations for 1978-1995'. Review of World Economics 139(4), 601-624.

Kucera, D. and W. Milberg. 2000. "Gender segregation and gender bias in manufacturing trade expansion: Revisiting the "Wood Asymmetry". World Development 28(7), 1191-1210.

Kucera, D., and W. Milberg. 2003. "Deindustrialization and changes in manufacturing trade: factor content calculations for 1978-1995”. Review of World Economics 139 (4), 601-24, (2003).

Lall, S., M. Albaladejo .2004. "China's Competitive Performance: A Threat to East Asian Manufactured Exports?" World Development 32 (9), 1441-1466. 
Pearson, R. 1998. "Nimble fingers' revisited: Reflections on Women and Third World industrialisation in the late 20th Century". In C. Jackson and R. Pearson Feminist Visions of Development: Gender analysis and policy. Routledge, London and New York.

Rowthorn, R., and R. Ramaswamy .1999. “Growth, Trade and Deindustrialization”. IMF Staff Papers 46 (1), 18-32.

Sachs, J. D., H. J. Schatz, A. Deardorff and R. E. Hall .1994. "Trade and Jobs in U.S. Manufacturing”. Brookings Papers on Economic Activity 1994 (1), 1-84.

Schultz, T.P. 1990. "Women's changing participation in the labor force: A world perspective". Economic Development and Cultural Change 38 (3), 457-488.

Shafaeddin, S.M. 2004. "Is China's accession to WTO threatening exports of developing countries?" China Economic Review 15, 109-144.

Standing, G .1999. "Global feminization through flexible labor: a theme revisited", World Development 27 (3), 583-602.

Staveren, I. 2003. "Monitoring Gender Impacts of Trade", European Journal of Development Research 15 (1), 126-145.

Wood, A. 1991. "North-South Trade and Female Labour in Manufacturing: And Asymmetry". The Journal of Development Studies 27 (2), 168-189.

Wood, A. 1991. "How Much Does Trade with the South Affect Workers in the North?," World Bank Research Observer, World Bank Group, 6 (1), 19-36.

Yamamoto, Y., 2000. "Trade Expansion and Gender Wage Inequality in Japan", paper presented at IAFFE Conference in Istanbul, August 17, 2000. 


\section{APPENDIX}

Table A1. List of sectors

ISIC Rev. 3

Code Manufacturing sector definitions

15+16 Manufacture of food products and beverages, tobacco products

17 Manufacture of textiles

18 Manufacture of wearing apparel; dressing and dyeing of fur

19 Tanning and dressing of leather; manufacture of luggage, handbags, saddlery, harness and footwear

20 Manufacture of wood and of products of wood and cork, except furniture; manufacture of articles of straw and plaiting materials

$21+22$ Manufacture of paper and paper products; publishing, printing and reproduction of recorded media.

23 Manufacture of coke, refined petroleum products and nuclear fuel

24+25 Manufacture of chemicals and chemical products; manufacture and rubber and plastic products

26 Manufacture of other non-metallic mineral products

27 Manufacture of basic metals

28 Manufacture of fabricated metal products, except machinery and equipment

29+31+33 Manufacture of machinery and equipment nec; electrical machinery and apparatus nec; medical, precision and optical instruments, watches and clocks

30+32 Manufacture of office, accounting and computing machinery; radio, TV and communication equipment and apparatus

34 Manufacture of motor vehicles, trailers and semi-trailers

35 Manufacture of other transport equipment

36+37 Manufacture of furniture; manufacturing nec; recycling 
Table A2. Import penetration rates by country and country of origin

\begin{tabular}{|c|c|c|c|c|c|c|c|c|c|}
\hline \multirow[b]{3}{*}{ OECD-HI } & & \multicolumn{8}{|c|}{ Country of Origin } \\
\hline & & \multicolumn{3}{|c|}{$\%$} & \multirow{2}{*}{$\begin{array}{c}\% \\
\text { Change }\end{array}$} & \multirow[b]{2}{*}{ OECD-MI } & \multicolumn{2}{|l|}{$\%$} & \multirow{2}{*}{$\begin{array}{c}\% \\
\text { Change }\end{array}$} \\
\hline & & China & Change & OECD- HI & & & Change & ODCs & \\
\hline \multirow[t]{2}{*}{ Austria } & 1995-99 & 0.7 & 125 & 39.2 & 8 & 3.9 & 51 & 1.4 & 61 \\
\hline & $2000-06$ & 1.6 & & 42.5 & & 5.9 & & 2.3 & \\
\hline \multirow[t]{2}{*}{ Denmark } & 1995-99 & 1.0 & 132 & 34.1 & 15 & 1.3 & 96 & 1.7 & 37 \\
\hline & $2000-06$ & 2.4 & & 39.1 & & 2.6 & & 2.4 & \\
\hline \multirow[t]{2}{*}{ Finland } & 1995-99 & 0.5 & 253 & 23.1 & -7 & 1.0 & 135 & 1.5 & 47 \\
\hline & $2000-06$ & 1.9 & & 21.4 & & 2.4 & & 2.1 & \\
\hline \multirow[t]{2}{*}{ France } & 1996-99 & 0.7 & 132 & 19.2 & 10 & 0.7 & 104 & 1.6 & 22 \\
\hline & $2000-06$ & 1.6 & & 21.1 & & 1.4 & & 2.0 & \\
\hline \multirow[t]{2}{*}{ Germany } & $1995-99$ & 0.7 & 114 & 17.9 & 17 & 2.2 & 69 & 1.5 & 26 \\
\hline & $2000-06$ & 1.5 & & 20.9 & & 3.8 & & 1.9 & \\
\hline \multirow[t]{2}{*}{ Greece } & $1995-98$ & 1.4 & 104 & 41.0 & -16 & 2.0 & 66 & 5.6 & -3 \\
\hline & 2004-06 & 2.8 & & 34.5 & & 3.4 & & 5.5 & \\
\hline \multirow[t]{2}{*}{ Ireland } & 1995-99 & 0.6 & 246 & 43.9 & -18 & 0.6 & 63 & 3.9 & -37 \\
\hline & $2000-06$ & 2.2 & & 35.8 & & 1.0 & & 2.5 & \\
\hline \multirow[t]{2}{*}{ Italy } & 1995-99 & 0.5 & 146 & 15.8 & 9 & 0.9 & 89 & 1.6 & 40 \\
\hline & $2000-06$ & 1.2 & & 17.2 & & 1.6 & & 2.3 & \\
\hline \multirow[t]{2}{*}{ Japan } & 1995-99 & 1.0 & 132 & 3.8 & 14 & 0.1 & 55 & 1.1 & 33 \\
\hline & 2000-04 & 2.3 & & 4.3 & & 0.1 & & 1.5 & \\
\hline \multirow[t]{2}{*}{ Rep. of Korea } & 1995-99 & 1.3 & 132 & 13.5 & -17 & 0.3 & -7 & 2.0 & 8 \\
\hline & $2000-06$ & 3.1 & & 11.3 & & 0.3 & & 2.1 & \\
\hline \multirow[t]{2}{*}{ Netherlands } & 1995-99 & 1.2 & 340 & 41.8 & 6 & 1.5 & 81 & 4.5 & 32 \\
\hline & $2000-06$ & 5.1 & & 44.3 & & 2.7 & & 6.0 & \\
\hline \multirow[t]{2}{*}{ Portugal } & 1996-99 & 0.3 & 82 & 32.1 & 12 & 0.4 & 283 & 1.4 & 31 \\
\hline & $2000-06$ & 0.6 & & 35.9 & & 1.6 & & 1.8 & \\
\hline \multirow[t]{2}{*}{ Spain } & 1996-99 & 0.7 & 140 & 23.2 & 8 & 0.6 & 162 & 1.5 & 46 \\
\hline & $2000-06$ & 1.7 & & 25.2 & & 1.6 & & 2.3 & \\
\hline \multirow[t]{2}{*}{ Sweden } & $1995-99$ & 0.3 & 230 & 28.6 & 8 & 0.9 & 142 & 0.8 & 57 \\
\hline & $2000-06$ & 1.0 & & 30.9 & & 2.2 & & 1.3 & \\
\hline \multirow[t]{2}{*}{ UK } & 1995-99 & 0.5 & 399 & 23.6 & 18 & 0.7 & 134 & 2.4 & 24 \\
\hline & $2000-05$ & 2.4 & & 28.0 & & 1.6 & & 3.0 & \\
\hline \multirow[t]{2}{*}{ US } & 1997-99 & 0.2 & 102 & 7.1 & 6 & 2.0 & 23 & 1.9 & -8 \\
\hline & $2000-06$ & 0.5 & & 7.5 & & 2.4 & & 1.8 & \\
\hline
\end{tabular}


Table A2 (cont.) Import penetration rates by country and country of origin

\begin{tabular}{|c|c|c|c|c|c|c|c|c|c|}
\hline \multirow{3}{*}{\multicolumn{2}{|c|}{ OECD-MI countries }} & \multicolumn{8}{|c|}{ Country of Origin } \\
\hline & & \multirow{3}{*}{$\begin{array}{c}\text { China } \\
0.6\end{array}$} & \multirow{3}{*}{$\begin{array}{c}\% \\
\text { Change } \\
349\end{array}$} & \multirow{3}{*}{$\frac{\text { OECD-HI }}{31.6}$} & \multirow{3}{*}{$\begin{array}{c}\% \\
\text { Change } \\
17\end{array}$} & \multirow{3}{*}{$\frac{\text { OECD-MI }}{6.2}$} & \multirow{3}{*}{$\begin{array}{c}\begin{array}{c}\% \\
\text { Change }\end{array} \\
8\end{array}$} & \multirow{3}{*}{$\begin{array}{c}\text { ODCs } \\
1.3\end{array}$} & \multirow{3}{*}{$\begin{array}{c}\% \\
\text { Change } \\
76\end{array}$} \\
\hline & & & & & & & & & \\
\hline \multirow[t]{2}{*}{ Czech Rep. } & 1995-99 & & & & & & & & \\
\hline & $2000-05$ & 2.8 & & 36.8 & & 6.7 & & 2.4 & \\
\hline \multirow[t]{2}{*}{ Hungary } & 1995-99 & 0.9 & 272 & 43.5 & 5 & 3.6 & 55 & 4.2 & 11 \\
\hline & $2000-05$ & 3.5 & & 45.6 & & 5.7 & & 4.7 & \\
\hline \multirow[t]{2}{*}{ Slovak Rep. } & 1995-99 & 0.6 & 270 & 33.8 & 31 & 18.0 & -7 & 2.9 & 19 \\
\hline & $2000-05$ & 2.2 & & 44.3 & & 16.7 & & 3.4 & \\
\hline \multirow[t]{2}{*}{ Slovenia } & 1995-99 & 0.4 & 376 & 30.4 & 33 & 2.8 & 109 & 2.9 & 68 \\
\hline & $2000-07$ & 1.8 & & 40.5 & & 5.9 & & 4.9 & \\
\hline \multirow[t]{2}{*}{ Turkey } & 1995-99 & 0.7 & 191 & 23.5 & -6 & 0.4 & 271 & 4.4 & 25 \\
\hline & $2000-05$ & 2.0 & & 22.1 & & 1.4 & & 5.5 & \\
\hline \multicolumn{10}{|l|}{$O D C s$} \\
\hline \multirow[t]{2}{*}{ Bulgaria } & 1996-99 & 0.5 & 541 & 24.7 & 38 & 3.2 & 181 & 10.3 & -25 \\
\hline & 2000-07 & 3.0 & & 34.0 & & 9.1 & & 7.7 & \\
\hline \multirow[t]{2}{*}{ India } & 1998-99 & 0.5 & 185 & 7.3 & 6 & 0.08 & 46 & 3.2 & 0 \\
\hline & $2000-05$ & 1.4 & & 7.7 & & 0.12 & & 3.2 & \\
\hline \multirow[t]{2}{*}{ Indonesia } & 1998-99 & 1.1 & 137 & 23.6 & -36 & 0.3 & -42 & 5.5 & 22 \\
\hline & 2000-06 & 2.5 & & 15.1 & & 0.2 & & 6.7 & \\
\hline \multirow[t]{2}{*}{ Jordan } & 1995-99 & 2.1 & 257 & 29.6 & 3 & 2.4 & 40 & 11.6 & 17 \\
\hline & $2000-07$ & 7.3 & & 30.4 & & 3.4 & & 13.6 & \\
\hline \multirow[t]{2}{*}{ Kazakhstan } & 1995-99 & 0.3 & 2306 & 7.0 & 324 & 1.6 & 248 & 10.5 & 160 \\
\hline & 2000-07 & 8.1 & & 29.7 & & 5.6 & & 27.4 & \\
\hline \multirow[t]{2}{*}{ Lithuania } & 1995-99 & 0.2 & 1034 & 39.9 & -7 & 11.4 & 10 & 15.8 & -31 \\
\hline & $2000-07$ & 2.5 & & 37.2 & & 12.5 & & 10.9 & \\
\hline \multirow[t]{2}{*}{ Philippines } & 1996-99 & 1.5 & 147 & 39.1 & 11 & 0.3 & -27 & 9.6 & 31 \\
\hline & 2001-05 & 3.7 & & 43.3 & & 0.2 & & 12.5 & \\
\hline \multirow[t]{2}{*}{ Romania } & 1995-99 & 0.3 & 566 & 19.9 & 74 & 2.3 & 305 & 1.3 & 150 \\
\hline & $2000-07$ & 2.1 & & 34.6 & & 9.4 & & 3.2 & \\
\hline \multirow[t]{2}{*}{ Thailand } & $1996-98$ & 1.6 & 186 & 27.2 & -14 & 0.5 & -38 & 7.3 & 20 \\
\hline & $2000-06$ & 4.4 & & 23.5 & & 0.3 & & 8.7 & \\
\hline
\end{tabular}


Table A3. Country-level total manufacturing employment effects from change in trade structure (with respect to trade partners)

\begin{tabular}{|c|c|c|c|c|c|c|c|}
\hline & $\begin{array}{r}\begin{array}{r}\text { Absolute } \\
\text { effects from } \\
\text { trade }\end{array} \\
\end{array}$ & $\begin{array}{r}\text { Change } \\
\text { Relative to } \\
\text { 1990s mfg. } \\
\text { emply (\%) }\end{array}$ & $\begin{array}{r}\text { Realized } \\
\text { change from } \\
1990 \text { s to } \\
2000 \text { s }(\%)\end{array}$ & & $\begin{array}{r}\text { Absolute } \\
\text { effects } \\
\text { from } \\
\text { trade }\end{array}$ & $\begin{array}{r}\text { Change } \\
\text { Relative to } \\
\text { 1990s mfg. } \\
\text { emply (\%) }\end{array}$ & $\begin{array}{r}\text { Realized } \\
\text { change from } \\
1990 \text { s to } \\
2000 \text { s }(\%) \\
\end{array}$ \\
\hline OECD HI & & & & $O E C D M I$ & & & \\
\hline Austria & 100956 & 13.3 & -5.7 & Czech Rep. & 212095 & 15.8 & -2.7 \\
\hline China & -8893 & -1.2 & & China & -73389 & -5.5 & \\
\hline North & 105061 & 13.8 & & North & 333720 & 24.8 & \\
\hline South & 4788 & 0.6 & & South & -48235 & -3.6 & \\
\hline Denmark & -15194 & -3.0 & -10.9 & Hungary & 99367 & 11.2 & 2.8 \\
\hline China & -11266 & -2.3 & & China & -51891 & -5.8 & \\
\hline North & 16349 & 3.3 & & North & 136284 & 15.3 & \\
\hline South & -20277 & -4.1 & & South & 14974 & 1.7 & \\
\hline Finland & -4134 & -1.0 & 5.4 & Slovak Rep. & 784598 & 256.0 & 17.2 \\
\hline China & -16866 & -3.9 & & China & -34308 & -11.2 & \\
\hline North & 21745 & 5.0 & & North & 830373 & 270.9 & \\
\hline South & -9013 & -2.1 & & South & -11467 & -3.7 & \\
\hline France & -188258 & -4.5 & -0.1 & Slovenia & 6236 & 2.2 & -4.6 \\
\hline China & -75863 & -1.8 & & China & -11708 & -4.1 & \\
\hline North & -74544 & -1.8 & & North & 18628 & 6.5 & \\
\hline South & -37851 & -0.9 & & South & -684 & -0.2 & \\
\hline Germany & 359375 & 4.2 & -3.1 & Turkey & 59129 & 5.5 & 66.9 \\
\hline China & -33355 & -0.4 & & China & -53206 & -4.9 & \\
\hline North & 332756 & 3.9 & & North & 216575 & 20.0 & \\
\hline South & 59974 & 0.7 & & South & -104240 & -9.6 & \\
\hline Greece & 6593 & 1.2 & -0.6 & $O D C s$ & & & \\
\hline China & -15187 & -2.7 & & Bulgaria & -932843 & -134.9 & -13.7 \\
\hline North & 32763 & 5.7 & & China & -192201 & -27.8 & \\
\hline South & -10984 & -1.9 & & North & -265607 & -38.4 & \\
\hline Ireland & -12765 & -4.9 & 7.9 & South & -475036 & -68.7 & \\
\hline China & -10735 & -4.1 & & India & -250269 & -3.2 & 0.1 \\
\hline North & -3608 & -1.4 & & China & -146276 & -1.8 & \\
\hline South & 1578 & 0.6 & & North & -107741 & -1.4 & \\
\hline Italy & -395955 & -8.1 & 0.1 & South & 3748 & 0.0 & \\
\hline China & -70729 & -1.5 & & Indonesia & 567790 & 13.6 & 5.2 \\
\hline North & -215405 & -4.4 & & China & -41556 & -1.0 & \\
\hline South & -109821 & -2.3 & & North & 703791 & 16.9 & \\
\hline Japan & 4798 & 0.0 & -13.4 & South & -94445 & -2.3 & \\
\hline China & -147086 & -1.5 & & Jordan & 53578 & 62.3 & 49.7 \\
\hline North & 160843 & 1.6 & & China & -12594 & -14.7 & \\
\hline South & -8959 & -0.1 & & North & 66377 & 77.2 & \\
\hline Netherlands & 78741 & 7.3 & -2.6 & South & -204 & -0.2 & \\
\hline China & -36176 & -3.3 & & Kazakhstan & -89414 & -18.5 & -14.4 \\
\hline North & 104308 & 9.6 & & China & -72412 & -15.0 & \\
\hline South & 10609 & 1.0 & & North & -223726 & -46.3 & \\
\hline Portugal & 23799 & 2.3 & -1.7 & South & 206724 & 42.8 & \\
\hline China & -4625 & -0.4 & & Lithuania & 155423 & 72.2 & 19.6 \\
\hline North & 37568 & 3.6 & & China & -42312 & -19.7 & \\
\hline South & -9144 & -0.9 & & North & 156800 & 72.9 & \\
\hline Rep. of Korea & 195634 & 7.5 & -0.6 & South & 40936 & 19.0 & \\
\hline China & 90736 & 3.5 & & Philippines & 63055 & 5.7 & -10.7 \\
\hline North & 8157 & 0.3 & & China & 23696 & 2.2 & \\
\hline South & 96741 & 3.7 & & North & 45651 & 4.2 & \\
\hline Spain & -284884 & -11.1 & 18.7 & South & -6292 & -0.6 & \\
\hline China & -73793 & -2.9 & & Romania & -416654 & -18.1 & -12.9 \\
\hline North & -106557 & -4.2 & & China & -119845 & -5.2 & \\
\hline South & -104534 & -4.1 & & North & -2187 & -0.1 & \\
\hline Sweden & -4587 & -0.6 & -6.4 & South & -294622 & -12.8 & \\
\hline China & -3526 & -0.5 & & Thailand & 288648 & 13.1 & 43.9 \\
\hline North & 5855 & 0.8 & & China & -63041 & -2.9 & \\
\hline South & -6916 & -0.9 & & North & 356179 & 16.2 & \\
\hline UK & -273946 & -5.5 & -15.4 & South & -4491 & -0.2 & \\
\hline China & -120668 & -2.4 & & & & & \\
\hline North & -92124 & -1.9 & & & & & \\
\hline South & -61154 & -1.2 & & & & & \\
\hline US & -1735219 & -9.3 & -9.1 & & & & \\
\hline China & -743656 & -4.0 & & & & & \\
\hline North & -433366 & -2.3 & & & & & \\
\hline South & -558196 & -3.0 & & & & & \\
\hline
\end{tabular}


Table A4. Country-level female manufacturing employment effects from change in trade structure (with respect to trade partners)

\begin{tabular}{|c|c|c|c|c|c|c|c|}
\hline & $\begin{array}{r}\text { Absolute } \\
\text { effects } \\
\text { from } \\
\text { trade }\end{array}$ & $\begin{array}{r}\text { Change } \\
\text { Relative to } \\
\text { 1990s female } \\
\text { mfg. emply } \\
(\%)\end{array}$ & $\begin{array}{r}\text { Realized } \\
\text { change from } \\
1990 \text { s to } \\
2000 \text { s }(\%)\end{array}$ & & $\begin{array}{r}\text { Absolute } \\
\text { effects } \\
\text { from } \\
\text { trade }\end{array}$ & $\begin{array}{r}\text { Change } \\
\text { Relative to } \\
1990 \text { s female } \\
\text { mfg. emply } \\
(\%)\end{array}$ & $\begin{array}{r}\text { Realized } \\
\text { change from } \\
1990 \text { s to } \\
2000 \text { s }(\%)\end{array}$ \\
\hline$O E C D H I$ & & & & $O E C D M I$ & & & \\
\hline Austria & 25483.0 & 12.4 & -10.8 & Czech Rep. & 104552.1 & 19.5 & -6.9 \\
\hline China & -2129.6 & -1.0 & & China & -37621.8 & -7.0 & \\
\hline North & 25373.6 & 12.3 & & North & 162591.7 & 30.3 & \\
\hline South & 2238.9 & 1.1 & & South & -20417.9 & -3.8 & \\
\hline Denmark & 674.5 & 0.5 & -16.0 & Hungary & 30482.9 & 8.5 & 1.9 \\
\hline China & -3926.2 & -2.6 & & China & -17658.1 & -4.9 & \\
\hline North & 9070.5 & 6.1 & & North & 40085.1 & 11.2 & \\
\hline South & -4469.8 & -3.0 & & South & 8055.9 & 2.2 & \\
\hline Finland & -10868.1 & -8.9 & 4.5 & Slovak Rep. & 474294.6 & 277.3 & -17.3 \\
\hline China & -5697.8 & -4.6 & & China & -15010.9 & -8.8 & \\
\hline North & -2498.6 & -2.0 & & North & 491420.7 & 287.3 & \\
\hline South & -2671.7 & -2.2 & & South & -2115.3 & -1.2 & \\
\hline France & -54952.6 & -4.4 & -1.8 & Slovenia & -2087.7 & -1.8 & -10.5 \\
\hline China & -29128.9 & -2.4 & & China & -5530.0 & -4.8 & \\
\hline North & -12947.7 & -1.0 & & North & 4747.0 & 4.1 & \\
\hline South & -12875.9 & -1.0 & & South & -1304.7 & -1.1 & \\
\hline Germany & 94583.3 & 3.9 & -3.6 & Turkey & -34046.9 & -14.2 & \\
\hline China & -17946.1 & -0.7 & & China & -9374.5 & -3.9 & \\
\hline North & 103876.1 & 4.3 & & North & 3854.4 & 1.6 & \\
\hline South & 8653.3 & 0.4 & & South & -28526.8 & -11.9 & \\
\hline Greece & -11465.4 & -6.9 & -10.2 & $O D C s$ & & & \\
\hline China & -4020.0 & -2.4 & & Bulgaria & -412789.5 & -119.7 & -9.7 \\
\hline North & -9032.5 & -5.4 & & China & -100847.9 & -29.2 & \\
\hline South & 1587.1 & 1.0 & & North & -90050.8 & -26.1 & \\
\hline Ireland & -3934.1 & -5.4 & 4.9 & South & -221890.8 & -64.3 & \\
\hline China & -3738.8 & -5.2 & & India & -16605.9 & -1.8 & -4.2 \\
\hline North & -1600.0 & -2.2 & & China & -13343.8 & -1.4 & \\
\hline South & 1404.7 & 1.9 & & North & -15476.5 & -1.6 & \\
\hline Italy & -97439.0 & -6.7 & -0.1 & South & 12214.4 & 1.3 & \\
\hline China & -23590.8 & -1.6 & & Indonesia & 270129.4 & 13.7 & 5.1 \\
\hline North & -53403.6 & -3.7 & & China & -15367.8 & -0.8 & \\
\hline South & -20444.7 & -1.4 & & North & 298486.5 & 15.1 & \\
\hline Japan & -68793.8 & -2.0 & -16.4 & South & -12989.3 & -0.7 & \\
\hline China & -99928.8 & -2.9 & & Jordan & 16277.5 & 193.9 & 109.4 \\
\hline North & 36178.2 & 1.0 & & China & -2350.2 & -28.0 & \\
\hline South & -5043.2 & -0.1 & & North & 17551.2 & 209.1 & \\
\hline Netherlands & 8290.8 & 4.0 & 1.4 & South & 1076.5 & 12.8 & \\
\hline China & -7420.4 & -3.6 & & Kazakhstan & -12975.3 & -7.1 & -23.3 \\
\hline North & 15218.1 & 7.3 & & China & -17193.6 & -9.5 & \\
\hline South & 493.1 & 0.2 & & North & -48694.9 & -26.8 & \\
\hline Portugal & -2407.5 & -0.6 & -0.1 & South & 52913.3 & 29.1 & \\
\hline China & -1738.3 & -0.4 & & Lithuania & 71047.2 & 62.2 & 5.9 \\
\hline North & 2183.4 & 0.5 & & China & -20718.8 & -18.2 & \\
\hline South & -2852.7 & -0.7 & & North & 71899.4 & 63.0 & \\
\hline Rep.of Korea & 37642.9 & 4.6 & -3.4 & South & 19866.6 & 17.4 & \\
\hline China & 15395.8 & 1.9 & & Philippines & 33112.5 & 6.5 & -3.3 \\
\hline North & 15738.7 & 1.9 & & China & 14486.3 & 2.9 & \\
\hline South & 6508.3 & 0.8 & & North & 16329.5 & 3.2 & \\
\hline Spain & -65453.6 & -11.4 & 31.6 & South & 2296.6 & 0.5 & \\
\hline China & -24180.2 & -4.2 & & Romania & -116287.5 & -11.5 & -6.8 \\
\hline North & -13469.9 & -2.3 & & China & -52772.7 & -5.2 & \\
\hline South & -27803.5 & -4.8 & & North & 44448.5 & 4.4 & \\
\hline Sweden & 3103.1 & 2.0 & 10.9 & South & -107963.4 & -10.7 & \\
\hline China & -352.0 & -0.2 & & Thailand & 90332.2 & 7.3 & 38.8 \\
\hline North & 3042.1 & 2.0 & & China & -37579.0 & -3.1 & \\
\hline South & 413.0 & 0.3 & & North & 155426.0 & 12.6 & \\
\hline UK & -78596.4 & -5.9 & -20.7 & South & -27514.7 & -2.2 & \\
\hline China & -35917.1 & -2.7 & & & & & \\
\hline North & -24469.2 & -1.8 & & & & & \\
\hline South & -18210.1 & -1.4 & & & & & \\
\hline US & -579029.6 & -9.7 & -12.6 & & & & \\
\hline China & -264375.8 & -4.4 & & & & & \\
\hline North & -123012.3 & -2.1 & & & & & \\
\hline South & -191641.5 & -3.2 & & & & & \\
\hline
\end{tabular}

